Article

\title{
Sustainable Utilization of Financial and Institutional Resources in Reducing Income Inequality and Poverty
}

\author{
Atta Ullah ${ }^{1}\left(\mathbb{D}\right.$, Zhao Kui $^{2, *}$, Saif Ullah ${ }^{3} \mathbb{D}$, Chen Pinglu ${ }^{1, *} \mathbb{1}$ and Saba Khan ${ }^{4}$ \\ 1 Institute of Poverty Reduction and Development, School of Management, Huazhong University of Science \\ and Technology, Wuhan 430074, China; attaullah142@hust.edu.cn \\ 2 School of Management, Huazhong University of Science and Technology, Wuhan 430074, China \\ 3 Management Sciences, SZABIST - Shaheed Zulfikar Ali Bhutto Institute of Science and Technology, \\ Karachi City 75600, Sindh, Pakistan; saifullah_142@yahoo.com \\ 4 Management Sciences, National University of Modern Languages, Multan Campus 66000, Punjab, Pakistan; \\ sabakhangishkori@gmail.com \\ * Correspondence: zhaokui2015@hust.edu.cn (Z.K.); cplcmhust@hust.edu.cn (C.P.)
}

check for

updates

Citation: Ullah, A.; Kui, Z.; Ullah, S.; Pinglu, C.; Khan, S. Sustainable Utilization of Financial and Institutional Resources in Reducing Income Inequality and Poverty. Sustainability 2021, 13, 1038. https://doi.org/10.3390/su13031038

Received: 25 December 2020

Accepted: 17 January 2021

Published: 20 January 2021

Publisher's Note: MDPI stays neutral with regard to jurisdictional claims in published maps and institutional affiliations.

Copyright: (c) 2021 by the authors. Licensee MDPI, Basel, Switzerland. This article is an open access article distributed under the terms and conditions of the Creative Commons Attribution (CC BY) license (https:// creativecommons.org/licenses/by/ $4.0 /)$.

\begin{abstract}
This study aims to determine the role of globalization, electronic government, financial development, concerning the moderation of institutional quality in reducing income inequality and poverty in One Belt One Road countries. The electronic government and regional integration of the economies of the One Belt One Road countries has increased globalization and can play a vital role in reducing income inequality and poverty. However, this globalization and digital transformation of government systems can only be beneficial in the presence of good institutional quality. The sample includes 64 One Belt One Road countries from 2003 to 2018. We employed a two-step system generalized method of moment (Sys-GMM) and a robustness check through Driscoll-Kraay standard errors regression. Our findings show that globalization, economic growth, e-government development, government expenditure, and inflation have a statistically significant and negative impact on income inequality and are key to eradicating income inequality and poverty. On the other hand, financial development, gross capital formation, and population size positively influence income inequality, which causes an increase in poverty and income inequality as financial development and population levels increase. Moderating variable institutional quality also positively impacts income inequality, which means that institutional quality in Belt and Road Countries is weak, as they are mostly developing countries that need to improve their systems. Moreover, the marginal effect also revealed that institutional quality has a corrective effect on the factors' relationship with income inequality. Our findings endorse and conclude that globalization and e-government development improve economic growth and eradicate poverty and income inequality by boosting digitalization, investments, job creation, and wage increases for semi-skilled and unskilled human capital in Belt and Road countries. The sustainable utilization of financial and institutional resources plays a vital role in reducing income inequality and poverty in Belt and Road countries.
\end{abstract}

Keywords: financial development; globalization; electronic government; economic growth; income inequality; poverty; institutional quality; panel cointegration; two-step Sys-GMM; Driscoll-Kraay Standard errors regression

JEL Classification: G00; O1; F6; R11; N7; D33; E00; C1

\section{Introduction}

The Sustainable Development Goals (SDGs) proclaimed a new goal in September 2015 to eradicate poverty at an extreme level by 2030, as determined by the proportion of the population surviving on less than $\$ 1.25$ a day. Recently, research has claimed that this goal is questionable with respect to being achievable by economic growth alone. The global 
\$1.25-a-day headcount will remain around 5-7\% in 2030 if there is no change in income distribution in countries, even in those with optimistic economic growth rates [1,2].

Also, the global extreme poverty database reported in the revised report of 2017 that it is recognized that poverty is a result of a variety of dimensions, including societal, party-political, and financial, and many scholars suggest that sustainable economic growth can be an essential tool in poverty reduction, which needs to be addressed in emerging countries. Zero poverty is the number one goal of sustainable development, which is a complex matter, and recently only a few studies have explored the impact of several factors on income inequality and poverty alleviation. However, the digital transformation and regional integration of the economies of the One Belt One Road countries have increased globalization and can play a vital role in reducing income inequality and poverty. However, this globalization and digital transformation can only be beneficial in the presence of institutional quality. Currently, rising inequality is the most controversial matter worldwide; the apparent reason for this disparity is access to economic resources. Therefore, researchers should explore income inequality and poverty factors [3].

Underneath the umbrella of Belt and Road Initiative (BRI), actor networks established six further economic corridors and subnetworks were established. The BRI master plan was outlined in the detailed framework blueprint entitled "Vision and Actions on Jointly Building the Silk Road Economic Belt and 21st Century Maritime Silk Road," released in March 2015 by the National Development and Reform Commission of China (NDRC). China's six BRI economic corridors are the New Eurasia Land Bridge Economic Corridor, the China-Mongolia-Russia Economic Corridor, the China Central Asia-West Asia Economic Corridor, the China-Indochina Economic Corridor, the China-Pakistan Economic Corridor, Bangladesh-China, and the India-Myanmar Economic Corridor. Promoting international trade policies and efficient processes, for instance, aims to significantly maximize development projects' economic values [4].

The growing integration of national economies and different places in the world in recent times offers a lesson and implies that BRI can work as a substance, particularly in trade upgradation, growing markets, regional practice, and raising socioeconomic status in the region. Moreover, Tambo et al. [5] and Ullah et al. [6] reported that China's BRI budget is estimated to exceed 1 trillion USD and involve more than 65 countries. The goal is to link China across Asia, Europe, the Middle East, and Africa. This linkage has direct and indirect global developmental impacts that can be separated into four categories: (1) information harnessing, technology, and globalization; (2) easier commerce and trade; (3) augmented energy resource safety; and (4) the drive toward global health and sustained development driven by poverty eradication. Belt and Road Initiative countries are developing, populated, lower-level income and poor countries. Therefore, it is necessary to highlight the factors affecting poverty and income inequality. The trend among Belt and Road Initiative countries in yearly average income inequality and poverty levels is demonstrated below in Figure 1.

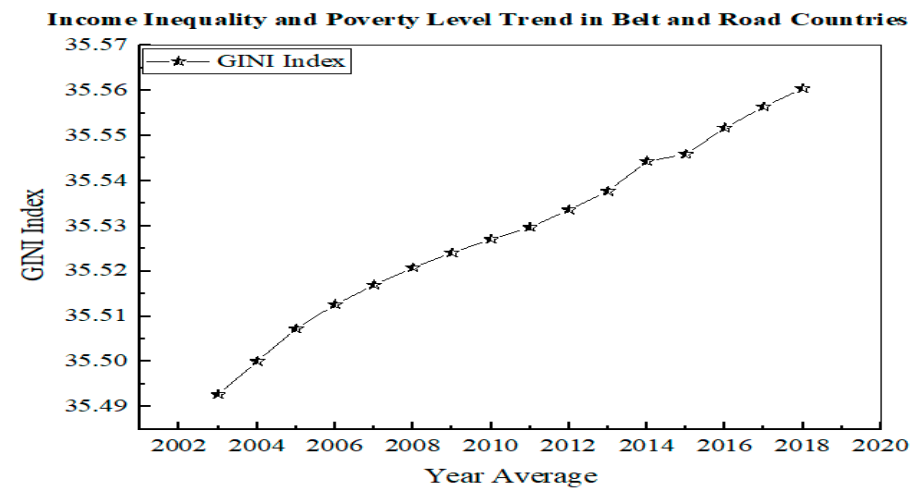

Figure 1. Trend of Income Inequality and Poverty Level (Source: Authors Estimations). 
Empirical studies based on different factors affecting income inequality and poverty have claimed that a sophisticated financial sector stimulates economic growth and largely alleviates income inequality [7-9]. A significant role is played by financial development to eradicate poverty, income inequality, and in the promotion of economic growth $[10,11]$. Also, Destek et al. [12] examined the impact of financial development, government expenditures, real income, and inflation on income inequality in Turkey over the period of 1990-2015 by using the Autoregressive Distributed Lag (ARDL) method. They found that income inequality was reduced by increasing real income and government expenditures. In the short run, inflation has a positive effect on income inequality while it is the inverse in the long run. They concluded that financial development, government expenditures, real income, and inflation are important factors in income inequality and poverty. Government expenditure is one of the key means to eradicate income inequality and poverty [1]. Another recent study of Alamanda [13] investigated the impact of various government expenditures on income inequality and poverty with a panel data set of 33 Indonesian provinces from 2005 to 2017 by employing random-effect, fixed-effect, and seemingly unrelated regression (SUR) systems. He found an insignificant effect of subsidy, grant expenditure, and social aid spending in eradicating income inequality and poverty. Simultaneously, a significant negative correlation existed between infrastructure expenditure and income inequality and poverty in urban and rural areas in Indonesia, with a greater impact in rural areas than urban areas.

Globalization is currently closely related to each country's socioeconomic development [14]. Several studies suggest that globalization is improving economic growth and eradicating poverty and income inequality by boosting investments, job creation, and wage increases for the semi-skilled and unskilled labor-intensive workforce [15-19]. A recent study investigated the impact of globalization on income inequality with financial, economic, and political country risk indicators using a dataset of 121 countries from 1984 to 2014. Their finding suggests that income distribution deteriorates with globalization, but that effect can be mitigated by financial and economic stability. They expressed that globalization is an important factor in determining income inequality and poverty [20].

Furthermore, thee digital transformation of e-government practices based on the United Nations' (UN) E-Government Survey are published as advancing the 2030 Agenda for Sustainable Development Goals (SDGs) based on a telecommunication infrastructure index, an online services index, and a human capital index. To pursue policies and measures to build resilience, it is critical for governments to support those distressed by shocks in attaining SDGs. They should figure out some ways to predict shocks and disasters and reduce their effects. Nowadays, governments are increasingly using digital technologies to give a progressive response to shocks and disasters to enhance the community's resilience. Simultaneously, a new vulnerability dimension has been added by the development of ICTs. This is required to boost resilience in those areas where governments have not reached or are not highly equipped to venture. It is noteworthy to move towards an approach in an information society that involves leaving no one behind, building resilience, and having sustainable development goals entrenched in the development of e-government [6]. Moreover, Goh and Law [21] stated that institutions are important because they provide the economy's incentive structure and shape economic changes toward growth, stagnation, or decline. Thus, it is widely believed that poor institutional quality has a detrimental effect on income distribution, which needs to be addressed. Apart from that, Abbas et al. [22] suggest that the quality of public institutions is of prime importance. Therefore, globalization, e-government development, and institutional governance quality should be directly explored with respect to regional integration to determine sustainable development related to income inequality and poverty.

The present study explores the role of sustainable utilization of financial and institutional resources in reducing Income Inequality and Poverty in Belt and Road countries. More, specifically, this study examines the impact of factors like globalization, e-government, financial development, and economic growth affecting income inequality 
and poverty. Apart from that, this study explores the moderating role of the institutional quality index as essential factors affecting income inequality of the Belt and Road Initiative in 64 sample countries from 2003 to 2018. This study contributes to the existing literature in three important respects. Firstly, this study uses international data that consists of the Belt and Road in both developed and developing countries that allows policymakers to evaluate the impact of factors on income inequality in one Belt and Road country. Second, this study incorporates the unexplored essential factors including e-government development, globalization, financial development, etc., as well as institutional quality as moderating variable by using interactive terms in the multiplicative models, highlighting the marginal effect of income inequality factors when institutional quality is present. Finally, the findings of two-step system GMM and DK regressions endorse that globalization and e-government development improve sustainable growth, thereby eradicating poverty and income inequality by boosting digitalization, investments, job creation, and wage increases for the semi-skilled and unskilled labor-intensive workforce Belt and Road Countries. Income inequality and poverty in Belt and Road countries can be reduced by using financial and institutional resources in a sustainable way.

The rest of the paper is based on a short overview of the literature, method, and material. Next, the system GMM results with a robustness check through Driscoll-Kraay standard errors regression along with the findings and discussion are reported. In the end, the conclusions and policy recommendations are offered with future directions.

\section{Literature Review}

Poverty can be defined by the proportion of the population surviving on less than $\$ 1.25$ a day. The global \$1.25-a-day headcount will remain at around $5-7 \%$ in 2030 if there is no change in income distribution in countries where even the economic growth rate is optimistic [1,2]. Also, the global extreme poverty database reported in the revised report of 2017 that a person is considered to live in extreme poverty if they live on less than 1.90 international dollars (\$) per day. Poverty has been measured in earlier studies by [23] and [24] but with a single variable proxy, economic growth by [25-27], government expenditure by $[1,28]$, trade openness and liberalization by $[29,30]$, inflation rate by $[23,31]$, infrastructure investment by $[32,33]$, while inflows of foreign direct investment have been studied by [34-36].

A recent study was conducted on financial development's effects on poverty, an outcome of wealth's unequal distribution in the selected member's countries of the Organization of Islamic Cooperation (OIC) over the period of 1990-2017 by employing panel data method. Their findings show that financial development, government size, inflation, openness, and economic growth were the main effective factors in poverty. Financial development has a positive effect on income inequality. Moreover, government size and inflation increase poverty, although poverty is eradicated by economic growth and openness [37]. Also, Jung and Cha [38] showed a positive impact on the financial development of income inequality in China. Moreover, recently Ngangu [39] conducted a panel fixed analysis of financial development and income disparity of 40 developing countries from 1995 to 2016 and found a relationship between financial market development and trade openness, which is an indicator of globalization and income inequality. Financial development increased income inequality in Latin America while it had a U-shaped relationship in sub-Saharan Africa. Another study reported that financial development and inclusion alleviate poverty and vulnerability to poverty in rural areas to a greater degree than in urban areas [40].

Economic growth significantly contributes to eradicating poverty and income inequality [41]. A research of Bouincha and Karim [42] examined the causality link between economic growth and inequality using data from 1990 to 2015 from 189 countries. Their findings show that economic growth negatively correlates with inequality, but a positive relationship exists for moderately developed and developing countries. Moreover, if a country's development reached an optimum level, then it reduced inequality. Another research was directed at investigating the relationship between income inequality and 
economic growth with two sample data. One is a full sample of 158 countries, and the second is a sample of 86 middle-income countries using the GMM and Granger causality test. They found that causality exists from economic growth to income inequality and reported that income inequality negatively relates to economic growth in middle-income economies [43].

The effect of globalization on inequality was explored by [44], and they found a substantial effect of globalization across income strata. These effects differ in states with relative endowment factors. Another study investigated globalization's effect on income inequality over the period of 1975-2018 in Bangladesh, and their findings show that globalization variables (such as imports, exports, remittance inflows, foreign direct investment (FDI), and foreign aid) have a long-term significant effect on income inequality. Moreover, in the long term, the remittance inflows, FDI, and exports are weakening income distribution, while imports and financial aid are improving Bangladesh's income distribution [45]. Several studies have claimed globalization as a means to eradicate poverty and income inequality $[29,46-48]$. Some studies have found that income inequality is rising due to globalization in several regions at different time periods [49-53].

The government's operations, interaction, and ways to serve the public are continuously changing because of technological advancements. From this perspective, information and communication technologies (ICT) have been utilized all over the world to efficiently deliver information and services to the people [54]. The E-government development index (EGDI) refers to the capacity of different countries and their readiness to utilize information and communication technologies (ICTs) in management at municipal and state levels [55]. Government spending per capita income showed a negative effect on poverty, while economic growth showed a positive impact [56]. Moreover, Anderson et al. [1] found that government spending and poverty have, on average, less negative relationships in sub-Saharan African countries while more negative relationships exist in Central Asian and Eastern European countries than in other regions. In addition, Destek et al. [12] found that, if government expenditures increased, this reduced the income inequality and poverty in Turkey over the period of 1990-2015.

The quality of the institutions (governance) is proposed by the World Bank's Worldwide Governance Indicators (WGIs). The WGIs comprise six indicators: voice and accountability, political stability and absence of violence, government effectiveness, regulatory quality, the rule of law, and corruption control. A study found that governance indicators negatively affect income and wealth inequality in Pakistan [57]. Institutional quality (governance) involves government policies to allocate resources for poverty alleviation and reduce economic inequality. Mixed results were reported and showed that governance has a negative impact on income inequality in emerging markets and developing countries, while in developed countries it has a positive impact [58].

The research of Akobeng [59] examined the gross fixed capital formation's effect on poverty by employing the dynamic two-way GMM to analyze the panel dataset of 41 subSaharan African countries from 1981 to 2010. Poverty was reduced by gross fixed capital formation. In terms of theory, gross fixed capital formation is recognized as a crucial factor in easing employment and economic growth, improving socioeconomic development, and decreasing poverty [60]. A study found that population growth has a significant positive impact on income inequality [61]. Inflation and income inequality have an inconsistent and contradictory relationship [62-65]. Some studies found that inflation positively impacts income inequality [66] and poverty $[67,68]$.

The conceptual framework of the study and variables is depicted below in Figure 2. 


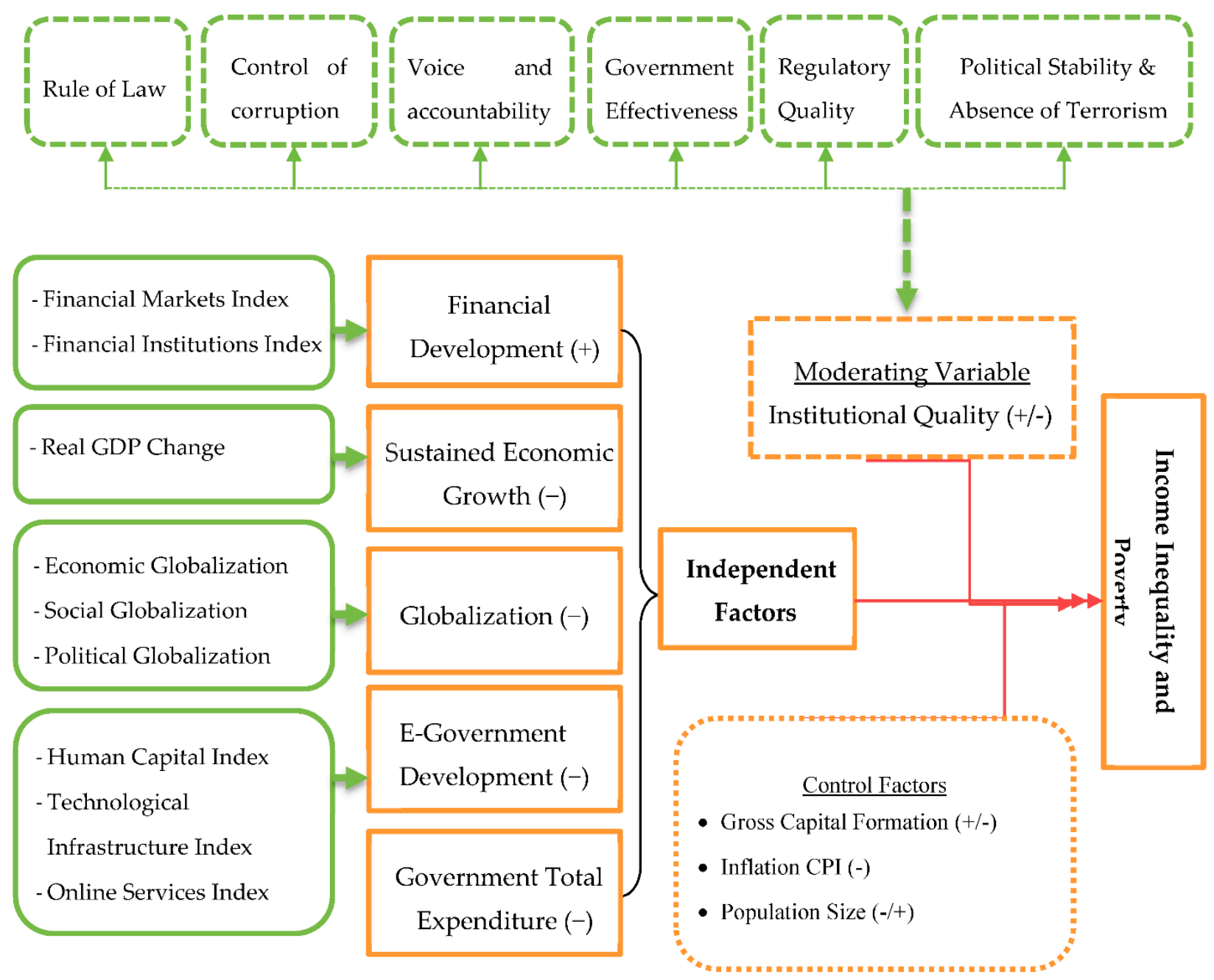

Figure 2. Conceptual Framework.

\section{Materials and Methods}

This study aims to determine the factors affecting income inequality and poverty in One Belt One Road countries. We used secondary data based on a deductive methodology from 2003 to 2018 of 64 Belt and Road initiative sample countries in STATA 15 and Origin-pro 2018. Sample Countries Belt \& Road Initiative include, in East Asia: China, Mongolia; Southeast Asia: Brunei, Cambodia, Indonesia, Laos, Malaysia, Myanmar, Philippines, Singapore, Thailand, and Vietnam. Timor-Leste is the part of one belt road but not included in the sample due to unavailability of complete sample data; Central Asia: Kazakhstan, Kyrgyzstan, Tajikistan, (Turkmenistan, and Uzbekistan are the part of one belt road but not included in the sample due to unavailability of complete sample data); South Asia: Bangladesh, Bhutan, India, Nepal, Pakistan, Sri Lanka (Afghanistan, and Maldives are the part of one belt road but not included in the sample due to unavailability of complete sample data); The Middle East: Bahrain, Iraq, Israel, Jordan, Kuwait, Lebanon, Oman, Qatar, Saudi Arabia, Syria and Egypt (Egypt also linked with northeast Africa), (Iran, Palestine, United Arab Emirates, and Yemen are the part of one belt road but not included in the sample due to unavailability of complete sample data); Africa: North Africa (Algeria, North Africa); West Africa (Gambia, The, Burkina Faso, Mali, Senegal); East Africa (Djibouti, Ethiopia, Mauritius, Rwanda, Kenya); Southern Africa (South Africa); Europe: Albania, Armenia, Azerbaijan, Belarus, Bulgaria, Croatia, Czech Republic, Estonia, Georgia, Hungary, Latvia, Lithuania, Macedonia, Moldova, Poland, Romania, Russia, Serbia, Slovakia, Slovenia, Turkey (also some part in western Asia), and Ukraine (Bosnia 
and Herzegovina, and Montenegro are the part of one belt road but not included in the sample due to unavailability of complete sample data).

The dependent variable poverty used the income inequality index, while the independent variables included financial development (FD), economic growth (EG), globalization index (GI), E-government development index (EGDI), and government expenditure (GE). The moderating variable was the institutional quality index (governance composite index), while control factors included gross capital formation (GCF), population size (PS), and inflation (INFL). The dependent variables income inequality and poverty were measured through the GINI Income Inequality Index based on income distribution from World Bank estimates and data obtained from the World Bank. The independent variables, such as financial development (FD) measured through a recent broad-based composite index, included overall financial sector development indicators developed by IMF staff and suggested by [69]. This index combines 20 indicators, including the financial market (the stock market) and financial institutions (banking and non-banking sector) indicators. So, the overall index of financial development has two sub-indices, namely financial institutions and markets. Moreover, both sub-indices are further divided into depth, access, and efficiency sub indicators. Consequently, this index better represents the country's financial system. Recently, this index has been suggested and employed by studies like [70,71]. Previous studies [37-40] found a positive impact of financial development on income inequality and poverty. Therefore, this study proposes the alternate $\mathrm{H}_{1}$ hypothesis, the positive impact of financial development and income inequality, which means financial development increases income inequality. Another independent variable, economic growth, shows the real GDP\% change rate taken from the world development indicators (WDI) of the World Bank [43]. Research hypothesis $\mathrm{H}_{2}$, related to economic growth, income inequality, and poverty, is that it is expected to contribute to the reduction of poverty and income inequality, as reported in past literature [41-43].

The globalization index has a range of 0-100 points, with higher values denoting greater globalization. Overall, globalization index contains the social, political, and economic dimensions of globalization. Social globalization is based on three extents: cultural proximity, personal contacts, and information flow. The sub index comprises trade in books, the number of Ikea stores, and McDonald's restaurants placed within the state. The personal contacts sub index contains foreign population, transfers, number of international letters, degree of tourism, and international telecom traffic. The information flow sub index comprises trade in newspapers, internet users, and share of households with a television set. Economic globalization depends on two facets, namely actual economic flows and restrictions to trade and capital. The actual economic flow sub index contains data on portfolio investment, FDI, and trade. The restrictions sub index considers taxes on international trade (as current revenue share), mean tariff rate, hidden import barriers, and capital controls index. The political globalization intensity is measured by the number of international organizations of which the country is a member, the number of treaties signed between two or more states, the number of UN peace missions a country participated in, and the number of embassies high commissions in a country. The globalization's data are taken from Zurich's Swiss Institute of Technology. Past studies, [44-48] and [29] claimed globalization as a means to eradicate poverty and income inequality. Therefore, the proposed hypothesis $\mathrm{H}_{3}$ is based on the findings mentioned in those studies.

Another independent variable, the E-government development index (EGDI), contains the telecommunication infrastructure index, online services index, and human capital index and data taken from a database of UN surveys of e-government knowledge. Surveys highlight the government's ways to certify good standards and safeguard online public facilities, including digital health, while collaborating with the private sector. EGDI is an approach in an information society that concerns leaving no one behind, building resilience, and sustainable development being entrenched in the development of e-government. How to step forward in this direction is also being explored by the survey. This matter is being explored by the background of an analysis of worldwide e-government development trends, which 
is founded on the EGDI. The relationship between e-government and income inequality has not been explored as such earlier through estimation. However, as per the review studies, hypothesis $\mathrm{H}_{4}$ concerning e-government is expected to eradicate the poverty and income inequality, which indicates a negative relation $[6,54,57]$. Government expenditure reported government spending as percent of GDP based on the general government's final consumption expenditure that contains overall current government expenditures for purchasing goods and services, including employees' compensation. National defense and security expenditures are also included in this, except military expenditures because they are included in government capital formation. The government expenditure data were taken from the World Bank and proxies followed by $[1,12,13]$. Our study followed the research hypothesis $\mathrm{H}_{5}$ as the government increases the expenditure, it reduces poverty and income inequality, which indicates a negative relationship between government expenditure and income inequality as found by $[1,12,56]$.

The moderating variable institutional quality index (governance composite index) measured, based on principle component analysis (PCA) of governance's six indicators: rule of law, control of corruption, voice and accountability, government effectiveness, regulatory quality, political stability, and the absence of violence and government effectiveness. Data about institutional quality indicators were obtained from the World Bank development indicators. Institutional quality still exhibits contradictory, mixed findings in different regions as well as in developed and developing countries. However, both theory and different studies such as $[22,57,58]$ showed these findings. Our study proposes hypothesis $\mathrm{H}_{6}$ that good institutional quality (governance) contributes to eradicating poverty and negatively impacts income inequality, while weak institutional quality (governance) causes an increase in poverty and income inequality.

Control factors, such as gross capital formation (GCF), are taken as the annual percentage growth rate of a country grounded on constant local currency and consist of outlays adding to the economy's fixed assets plus net variations in the inventories level. Fixed assets comprise railways, roads, offices, schools, private residential dwellings, hospitals, industrial and commercial buildings, purchases of plants, machinery, and equipment, land improvements such as drains, ditches, fences, etc. Inventories are a portion of goods held by firms to encounter unexpected/temporary fluctuations in sales/production and "work in progress". The data were taken from national accounts of the World Bank and OECD and proxy employed by $[59,60]$ and state that gross capital formation improve the employment and socioeconomic conditions which cause a reduction in poverty. Inflation is the percent change in the consumer price index that manifests the average change in prices for a basket of goods and services, which is consumer pay to buy, and it can be fixed or change over a specific time. The data were taken from the World Development Indicators of the World Bank. In the past, studies showed contradictory impacts and this proxy (as used by $[12,62-65,67]$. Moreover, population size is in millions, founded on the de facto population's definition that considered all residents regardless of citizenship or legal status. Data were taken from the United Nations Population Division and proxies by [61] and expected to be positive for the population on income inequality and poverty.

In this study, we employed the two-step Sys-GMM. Sys-GMM is best in examining the endogeneity biases, omitted variables, overidentifying restrictions, measurement errors, and autocorrelation in the panel dataset [72]. In the analysis, Sys-GMM is considered the best technique to control measurement errors and endogeneity issues [73]. A basis criterion for Sys-GMM application is $\mathrm{N}$ (the number of cross-sections) $>\mathrm{T}$ (period), which was fulfilled by the data of this study, where $\mathrm{T}=16$ and $\mathrm{N}=64(\mathrm{~N}>\mathrm{T})$. At first, GMM controls the autocorrelation, and then differentiation and results of a panel dataset of the study analyzed more effectively. The Hansen and Sargan test, which explores the instrument's reliability and controls the overidentifying restrictions that make the analysis the finest, was utilized to improve the analysis further. Two-step Sys-GMM and Arellano-Bond have one- and two-step variants, and two-step Sys-GMMs are efficient because they are robust to heteroscedasticity and autocorrelation. The econometric trick of the two-step Sys-GMM 
includes both OLS and 2SLS, where 2SLS indicates a special case of GMM. To deal with the potential endogeneity issues, the Sys-GMM estimator is best suited [22,74,75]. For the robustness check, DK regression standard errors approach was used, which corrects the problems of heteroscedasticity and auto-correlation [76,77]. Therefore, based on the above discussion, equations of the econometrics static and dynamic models are as follows:

$$
\text { Poverty (Income inequality) }=\int\left(\text { FD, EG, GI, EGDI, GE, GCF }+\int\right. \text { (Control Factors) }
$$

Functions of the two-step system GMM can be reported as:

$$
\begin{gathered}
Y_{\text {it }}=X_{i t} \beta+\vartheta \gamma_{i t-1}+\varepsilon_{\mathrm{I}}+\mu_{\mathrm{it}} \\
\Delta \gamma_{\mathrm{it}}=\Delta X_{\mathrm{i}, \mathrm{t}} \beta+\vartheta \gamma_{\mathrm{i}, \mathrm{t}-1}+\varepsilon_{\mathrm{I}}+\mu_{\mathrm{it}}
\end{gathered}
$$

where I denotes the cross-sectional units, of which there are 64 in our sample, $t$ expresses time, which is 16 years in our sample, and it is assumed that fixed individual effect $c i$ is composed of a term of error. Moreover, $\varepsilon$ as follows: E [ci] $]=\mathrm{E}=\left[\varepsilon_{\mathrm{it}}\right]=\left[\mathrm{c}_{\mathrm{i}} \varepsilon_{\mathrm{it}}\right]=0$, which would hold the properties as reflecting idiosyncratic shocks while the differenced operator is $\Delta$ sign. $\varphi$ represents year dummies which controls for common shock such as the global financial crises of $2007-2009$ as adopted by the by following the $[75,78,79]$ studies. So, the two-step system GMM model can be written as:

Static model:

$$
\begin{aligned}
\text { Income }_{\text {Inequality }} & \left(\text { Poverty }_{i, t}\right. \\
& =\beta_{0}+\beta_{1}(F D)_{i, t}+\beta_{2}(E G)_{i, t}+\beta_{3}(G I)_{i, t}+\beta_{4}(E G D I)_{i, t}+\beta_{5}(G E)_{i, t}+\beta_{6}(\text { Conrol factors })_{i, t} \\
& +\varphi_{t}+\mu_{i, t}
\end{aligned}
$$

Dynamic model:

$$
\begin{aligned}
\text { Income }_{\text {Inequality }} & (\text { Poverty }) \\
& =\beta_{0}+\beta_{1}\left(\text { Income }_{\text {Inequality }}\right)_{i, t-1}+\beta_{2}(F D)_{i, t}+\beta_{3}(E G)_{i, t}+\beta_{4}(G I)_{i, t}+\beta_{5}(E G D I)_{i, t} \\
& +\beta_{6}(G E)_{i, t}+\beta_{7}(\text { Control factors })_{i, t}+\varphi_{t}+\mu_{i, t}
\end{aligned}
$$

The moderating impact of governance index interaction terms can be written as follows:

$$
\begin{aligned}
& \text { Income }_{\text {Inequality }}\left(\text { Poverty }=\beta_{0}+\beta_{1}\left(\text { Income }_{\text {Inequality }}\right)_{i, t-1}+\beta_{2}(F D)_{i, t}\right. \\
& +\beta_{3}(E G)_{i, t}+\beta_{4}(G I)_{i, t}+\beta_{5}(E G D I)_{i, t}+\beta_{6}(G E)_{i, t}+\beta_{7}(I Q)_{i, t} \\
& +\beta_{8}(F D * I Q)_{i, t}+\beta_{9}(E G * I Q)_{i, t}+\beta_{10}(G I * I Q)_{i, t} \\
& +\beta_{11}(E G D I * I Q)_{i, t}+\beta_{12}(G E * I Q)_{i, t}+\beta_{13}(\text { Control factors })_{i, t}+\varphi_{t}+\mu_{i, t}
\end{aligned}
$$

where $\beta_{0}$ is constant, $F D$ represents financial development, $E G$ represents economic growth, $G I$ indicates globalization index, EGDI is E-government development index, GE represents government expenditure, and control factors represent gross capital formation (GCF), population size (PS), and inflation (INFL), IQ indicates the PCA index of institutional quality Indicators, $\varphi$ represents year dummies (i.year), which controls for common shocks of fixed time effect, and $\mu$ represents the error term.

\section{Results and Discussion}

\subsection{Summary Statistic}

Table 1 describes the descriptive statistics of the selected dependent and independent variables and presents the summary statistics in terms of the mean, standard deviation, minimum and maximum values, skewness, Kurtosis, and observation count. All variables have 1024 observations for 64 countries over a period of 16 years from 2003-2018. The normal distribution probability trend curves of all the variables are demonstrated in Appendix A with Figure A1a-j, which shows that all the variables are distributed normally. 
Table 1. Descriptive Statistics (Source: Authors Own Estimations).

\begin{tabular}{lccccccc}
\hline Variables & Obs & Mean & Std.Dev. & Min & Max & Skew. & Kurt. \\
\hline (1) Poverty & 1024 & 35.639 & 6.593 & 24.8 & 63.378 & 1.172 & 6.167 \\
(2) FD & 1024 & 0.308 & 0.17 & 0.076 & 0.718 & 0.56 & 2.365 \\
(3) EG & 1024 & 4.945 & 3.708 & -7.08 & 17.29 & -0.089 & 4.741 \\
(4) GI & 1024 & 63.586 & 12.481 & 26.24 & 86.15 & -0.367 & 2.545 \\
(5) EGDI & 1024 & 0.48 & 0.166 & 0.14 & 0.834 & -0.077 & 2.282 \\
(6) GE & 1024 & 15.19 & 4.644 & 5.13 & 25.81 & -0.094 & 2.391 \\
(7) GCF & 1024 & 5.211 & 4.931 & -1.3 & 26.8 & 1.762 & 7.362 \\
(8) PS & 1024 & 69.328 & 223.1 & 0.4 & 1337.7 & 5.062 & 27.798 \\
(9) INFL & 1024 & 9.458 & 24.038 & -137.635 & 435.616 & 7.284 & 121.611 \\
(10) IQ & 1024 & 0 & 0.992 & -1.757 & 3.405 & 0.78 & 3.793 \\
(11) FD* IQ & 1024 & 0.07 & 0.421 & -1.134 & 2.445 & 2.74 & 16.405 \\
(12) EG* IQ & 1024 & -0.437 & 6.651 & -24.318 & 49.476 & 1.344 & 11.295 \\
(13) GI* IQ & 1024 & 6.011 & 67.638 & -137.045 & 290.59 & 1.307 & 6.001 \\
(14) EGDI* & 1024 & 0.075 & 0.58 & -1.314 & 2.84 & 1.693 & 8.492 \\
IQ & 1024 & 1.498 & 15.286 & -43.382 & 49.646 & 0.47 & 3.173 \\
(15) GE* IQ & & & & & & &
\end{tabular}

Table 2 shows the pairwise correlation between the variables. Results of Belt and Road Initiative countries show that GI and EGDI have a robust negative correlation with income inequality at a $1 \%$ significance level. Income inequality decreases as the concentration of GI and EGDI increases. GE also negatively correlates with income inequality with less than a 5\% significance level. On the other hand, EG significantly and positively correlates with income inequality at a $1 \%$ significance level. Income inequality increases as the degree of EG increases. FD and GCF also positively correlate with income inequality at a $10 \%$ significance level. However, control variable PS has a highly significant and positive relationship with income inequality at a $1 \%$ significance level. Interestingly, INFL is negatively correlated with income inequality, which depicts that income inequality decreases as INFL increases. The moderating variable IQ also positively correlates with income inequality at a $5 \%$ significance level. The FD and GI interaction with IQ is highly significant and positively impacts income inequality at a 10\% significance level. EG with 10\%, EGDI with 5\%, and GE interaction with IQ have a positive impact on income inequality. All independent variables have shown a $1 \%$ significance level. In this study, a significant correlation exists among income inequality, and explanatory findings have strongly supported our research objective and hypotheses.

\subsection{Stationary and Panel Cointegration Test.}

Table 3 demonstrates the data stationary through ADF-Fisher Chi-square, PP-Fisher Chi-square unit root methods. Stationary test results show that all variables data are stationary at significance level (I0). However, in the PP-Fisher unit, root EGDI and institutional quality were stationary at the first difference (I1).

Table 4 of Westerlund, Pedroni, and Kao's test for cointegration shows that all panels are cointegrated in favor of the alternate hypothesis ( $\mathrm{Ha}$ ) and reject the null hypothesis (Ho) of no cointegration. 
Table 2. Pairwise Correlations (Source: Authors Own Estimations).

\begin{tabular}{|c|c|c|c|c|c|c|c|c|c|c|c|c|c|c|c|}
\hline Variables & -1 & -2 & -3 & -4 & -5 & -6 & -7 & -8 & -9 & -10 & -11 & -12 & -13 & -14 & -15 \\
\hline (1) Poverty & 1 & & & & & & & & & & & & & & \\
\hline (2) FD & $0.051 *$ & 1 & & & & & & & & & & & & & \\
\hline (3) EG & $0.091 * * *$ & $-0.167^{* * *}$ & 1 & & & & & & & & & & & & \\
\hline (4) GI & $-0.212^{* * *}$ & $0.423^{* * *}$ & $-0.361^{* * *}$ & 1 & & & & & & & & & & & \\
\hline (5) EGDI & $-0.244^{* * *}$ & $0.481 * * *$ & $-0.300 * * *$ & $0.441^{* * *}$ & 1 & & & & & & & & & & \\
\hline (6) GE & $-0.079 * *$ & $0.207^{* * *}$ & $-0.311^{* * *}$ & $0.340 * * *$ & $0.288^{* * *}$ & 1 & & & & & & & & & \\
\hline (7) GCF & $0.052 *$ & $-0.116^{* * *}$ & $0.339 * * *$ & $-0.186^{* * *}$ & $-0.168^{* * *}$ & $-0.083^{* * *}$ & 1 & & & & & & & & \\
\hline (8) PS & $0.087^{* * *}$ & $0.200^{* * *}$ & $0.165^{* * *}$ & $-0.063^{* *}$ & -0.043 & $-0.189^{* * * *}$ & 0.015 & 1 & & & & & & & \\
\hline (9) INFL & -0.03 & $-0.278^{* * *}$ & $0.187^{* * *}$ & $-0.285^{* * *}$ & $-0.211^{* * *}$ & $-0.267^{* * *}$ & $0.098^{* * *}$ & 0.026 & 1 & & & & & & \\
\hline (11) FD*IQ & $0.054 *$ & $0.387^{* * *}$ & -0.048 & $0.388^{* * *}$ & $0.365^{* * *}$ & $0.121^{* * *}$ & -0.045 & $-0.134^{* * *}$ & $-0.241^{* * *}$ & $0.873^{* * *}$ & 1 & & & & \\
\hline (12) EG*IQ & $0.057 *$ & $0.362 * * *$ & -0.044 & $0.407 * * *$ & $0.356^{* * *}$ & $0.252 * * *$ & -0.044 & $-0.088^{* * *}$ & $-0.243^{* * *}$ & $0.794^{* * *}$ & $0.674^{* * *}$ & 1 & & & \\
\hline (13) GI*IQ & $0.055^{*}$ & $0.407^{* * *}$ & $-0.095^{* * *}$ & $0.484^{* * *}$ & $0.456^{* * *}$ & $0.253^{* * *}$ & $-0.062 * *$ & $-0.113^{* * *}$ & $-0.303^{* * *}$ & $0.976^{* * *}$ & $0.928^{* * *}$ & $0.738^{* * *}$ & 1 & & \\
\hline (14) EGDI*IQ & $0.063^{* *}$ & $0.367^{* * *}$ & $-0.088^{* * *}$ & $0.444^{* * *}$ & $0.418^{* * *}$ & $0.197^{* * *}$ & $-0.055^{*}$ & $-0.109 * * *$ & $-0.290 * * *$ & $0.948^{* * *}$ & $0.937^{* * *}$ & $0.706^{* * *}$ & $0.987^{* * *}$ & 1 & \\
\hline (15) GE*IQ & 0.049 & $0.326^{* * *}$ & $-0.111^{* * *}$ & $0.396^{* * *}$ & $0.378^{* * *}$ & $0.266^{* * *}$ & $-0.073^{* *}$ & $-0.104 * * *$ & $-0.298 * * *$ & $0.951^{* * *}$ & $0.801^{* * *}$ & $0.696^{* * *}$ & $0.931 * * *$ & $0.906 * * *$ & 1 \\
\hline
\end{tabular}


Table 3. Results of Unit Root Tests (Source: Authors Own Estimations).

\begin{tabular}{ccccc}
\hline Variables & Lags & $\begin{array}{c}\text { ADF-Fisher } \\
\text { Chi-Square }\end{array}$ & $\begin{array}{c}\text { PP-Fisher } \\
\text { Chi-square }\end{array}$ & $\begin{array}{c}\text { Stationary } \\
\text { Decision }\end{array}$ \\
\hline Income & At Level & $25.4549^{* * *}$ & $18.0894^{* * *}$ & At Level (I0) \\
Inequality- & At First Diff & $18.0765^{* * *}$ & $17.5392^{* * *}$ & \\
Poverty & At Level & $18.8591^{* * *}$ & $5.9205^{* * *}$ & At Level (I0) \\
FD & At First Diff & $16.3177^{* * *}$ & $6.4895^{* * *}$ & \\
& At Level & $32.3067^{* * *}$ & $23.4003^{* * *}$ & At Level (I0)) \\
EG & At First Diff & $24.6514^{* * *}$ & $23.6135^{* * *}$ & \\
& At Level & $33.9651^{* * *}$ & $25.3210^{* * *}$ & At Level (I0) \\
GI & At First Diff & $27.7920^{* * *}$ & $28.9925^{* * *}$ & \multirow{2}{*}{ At First Diff (I1) } \\
& At Level & $4.7208^{* * *}$ & -4.0909 & \\
EGI & At First Diff & $8.6740^{* * *}$ & $2.1928^{* * *}$ & At Level (I0) \\
& At Level & $17.0109^{* * *}$ & $3.6946^{* * *}$ & \\
GCF & At First Diff & $14.9961^{* * *}$ & $4.0115^{* * *}$ & At Level (I0) \\
& At Level & $43.3331^{* * *}$ & $40.8112^{* * *}$ & \\
PS & At First Diff & $28.7674^{* * *}$ & $41.2652^{* * *}$ & At Level (I0) \\
& At Level & $10.8301^{* * *}$ & $10.2214^{* * *}$ & \\
INFL & At First Diff & $12.4916^{* * *}$ & $7.2312^{* * *}$ & At Level (I0) \\
& At Level & $31.0789^{* * *}$ & $17.3558^{* * *}$ & \\
IQ & At First Diff & $22.6760^{* * *}$ & $17.7233^{* * *}$ & At First Diff (I1) \\
\hline Note: ${ }^{* * *} p<0.01, * * p<0.05$, indicate significance at $1 \%$, and $5 \%$, levels, respectively. &
\end{tabular}

Table 4. Results of Panel Cointegration Test (Source: Authors Own Estimations).

\begin{tabular}{|c|c|c|}
\hline $\begin{array}{l}\text { Westerlund Test for } \\
\text { Cointegration }\end{array}$ & $\begin{array}{l}\text { Cointegrating Vector: } \\
\text { Panel Specific }\end{array}$ & Decision \\
\hline Variance ratio & $3.0222 * * *$ & All panels are cointegrated \\
\hline Pedroni test for cointegration & \multicolumn{2}{|c|}{$\begin{array}{c}\text { Kernel: Quad. Spectral with Newey-West Lags } \\
\text { Augmented lags: } 1 \text { (AIC) }\end{array}$} \\
\hline Modified Phillips-Perron $\mathrm{t}$ & $9.5628^{* * *}$ & \multirow{3}{*}{ All panels are cointegrated } \\
\hline Phillips-Perron $\mathrm{t}$ & $-15.9263^{* * *}$ & \\
\hline Augmented Dickey-Fuller t & $-14.1256^{* * *}$ & \\
\hline Kao test for cointegration & \multicolumn{2}{|c|}{$\begin{array}{c}\text { Kernel: Quad. Spectral with Newey-West Lags } \\
\text { Augmented lags: } 1 \text { (AIC) }\end{array}$} \\
\hline Modified Dickey-Fuller t & $3.8784 * * *$ & \multirow{5}{*}{ All panels are cointegrated } \\
\hline Dickey-Fuller $t$ & $2.4988^{* * *}$ & \\
\hline Augmented Dickey-Fuller t & $4.7772^{* * *}$ & \\
\hline $\begin{array}{l}\text { Unadjusted modified } \\
\text { Dickey-Fuller } \mathrm{t}\end{array}$ & $-4.7772 * * *$ & \\
\hline Unadjusted Dickey-Fuller t & $-5.0243 * * *$ & \\
\hline
\end{tabular}

\subsection{Direct Impact of Factors Affecting Income Inequality}

Table 5 shows the regression analysis, and Columns 1 and 2 show the static modeling techniques. The first column consists of "OLS" modeling. GI and EGDI both are with a $1 \%$ significance level and EG and GE also have a negative impact on income inequality in the Belt and Road Initiative countries. This means that these factors eradicate the level of income inequality and poverty. FD and GCF have a significant positive impact on income inequality, but FD with a $1 \%$ significance level. The control variable INFL with a $10 \%$ significance level has a negative impact on income inequality with an R2 value of 0.127 . PS also shows a negative but insignificant impact. The second column shows "fixed-effect" modeling; PS with a 5\% significance level as well as EG, GE, and INFL have a positive significant impact on income inequality. GI with a $1 \%$ significance level, as well as FD, EGDI, and GCF have a negative significant impact income inequality with an R2 value of 0.129 , which also favors the study's objective. The third and fourth columns show 
dynamic modeling; as per dynamic "OLS" FD, EG, EGDI, GCF, and PS have a positive significance on income inequality. Though INFL with a 10\% significance level as well GE and GI have significant negative impacts on income inequality with an R2 value of 0.967 , that supported the research. In Column 4, dynamic "fixed-effect" EG, EGDI, GE, GCF, and PS have a significant positive impact on income inequality. GI with a $1 \%$ significance level as well INFL have significant negative impacts on income inequality with a whole R2 value of 0.534 , which supports the research framework. FD also shows a negative impact on income inequality.

The fifth column in Table 5 reports the two-step system GMM estimations that indicate more accurate results. EG, GI, EGDI, and INFL with a $1 \%$ significance level show a negative and significant impact on income inequality. It means that these factors contribute to reducing inequality and poverty level. GE also shows a negative but statistically insignificant influence, while GCF and PS with a 1\% significance level but positivity. Also, FD shows a positive but insignificant impact on income inequality, which means that FD, GCF and PS cause an increase in poverty and income inequality. Overall, the model's results show that the AR (1) $p$-value is 0.000647 , which is less than $5 \%$, indicating the autocorrelation and serial correlation in first-order difference. The AR (2) $p$-value is 0.1053 , which is greater than $5 \%$. Its mean null hypothesis failure results in a rejection of the null hypothesis, and there is no second-order correlation. Furthermore, the Hansen test indicates that overidentifying restrictions are valid. The Hansen $p$-value is 0.191 , which is between 0.10 and 0.25 , which supports instrument reliability. The number of instruments, 52 , is less than the number of groups, 64 , and fails to reject the null hypothesis. In this model, Wald Chi-square test indicates that all variables are significant. Direct detailed results of Table 5 are reported below.

\subsection{Moderating Effect of Factors Affecting Income Inequality}

Table 6 shows the regression analysis of the moderating variable. Columns 1 and 2 show static modeling techniques. The first column consists of "OLS" modeling, FD with $1 \%$ significance level, GCF, and PS also have a significant positive impact concerning moderating variable IQ, though GI and EGDI have a $\%$ significance level and negative impact by taking moderating variable IQ with $R^{2}$ value displayed a 0.157 . Also, EG, GE, and INFL show a negative impact on income inequality. The second column shows "fixed-effect" modeling, PS with a 5\% significance level, and a positive significant impact concerning moderating variable IQ. Also, EG, GE, and INFL have a positive impact concerning moderating variable IQ. GI with a $1 \%$ significance level and FD, EGDI, and GCF have a negative significant impact by employing IQ with an $\mathrm{R}^{2}$ value of 0.130 , which favors the research objective. Columns 3 and 4 report dynamic modeling; as per dynamic, "OLS" FD, EG, EGDI, GCF, and PS have a positive significant impact concerning moderating variable IQ, though GI, GE, and INFL have a significant and negative impact by employing IQ with an $\mathrm{R}^{2}$ value of 0.967 . In dynamic "fixed-effect" Column 4, EG, EGDI, GE, GCF, and PS have a significant positive impact concerning moderating variable IQ. GI with a $1 \%$ significance level, FD, and INFL have significant negative impacts by taking IQ as moderating with a whole $\mathrm{R}^{2}$ value of 0.534 . 
Table 5. Direct Impact -Two-step System GMM (Source: Authors Own Estimations).

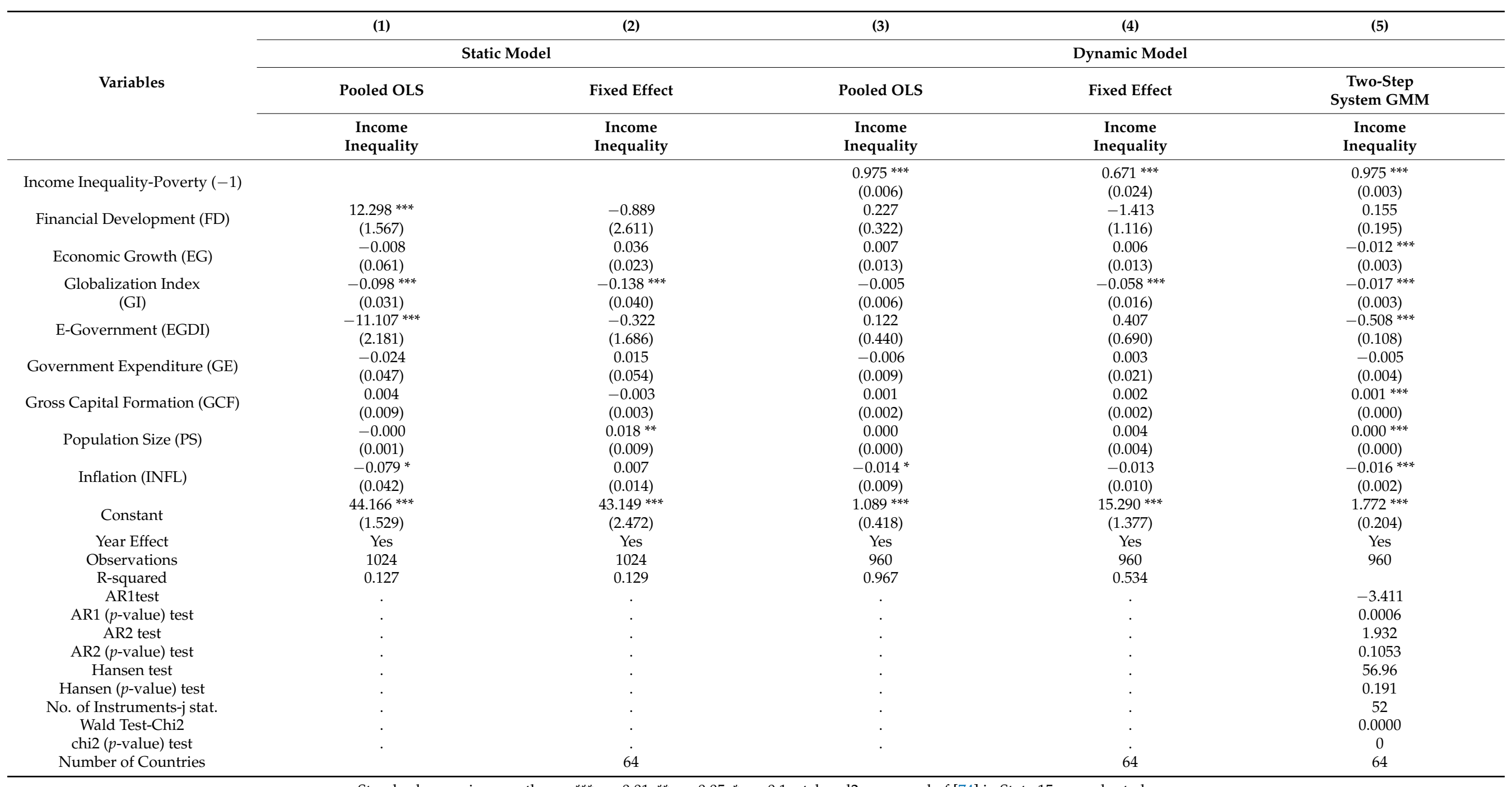


Table 6. Moderating effects of Institutional Quality-Two-step System GMMC (Source: Authors Own Estimations).

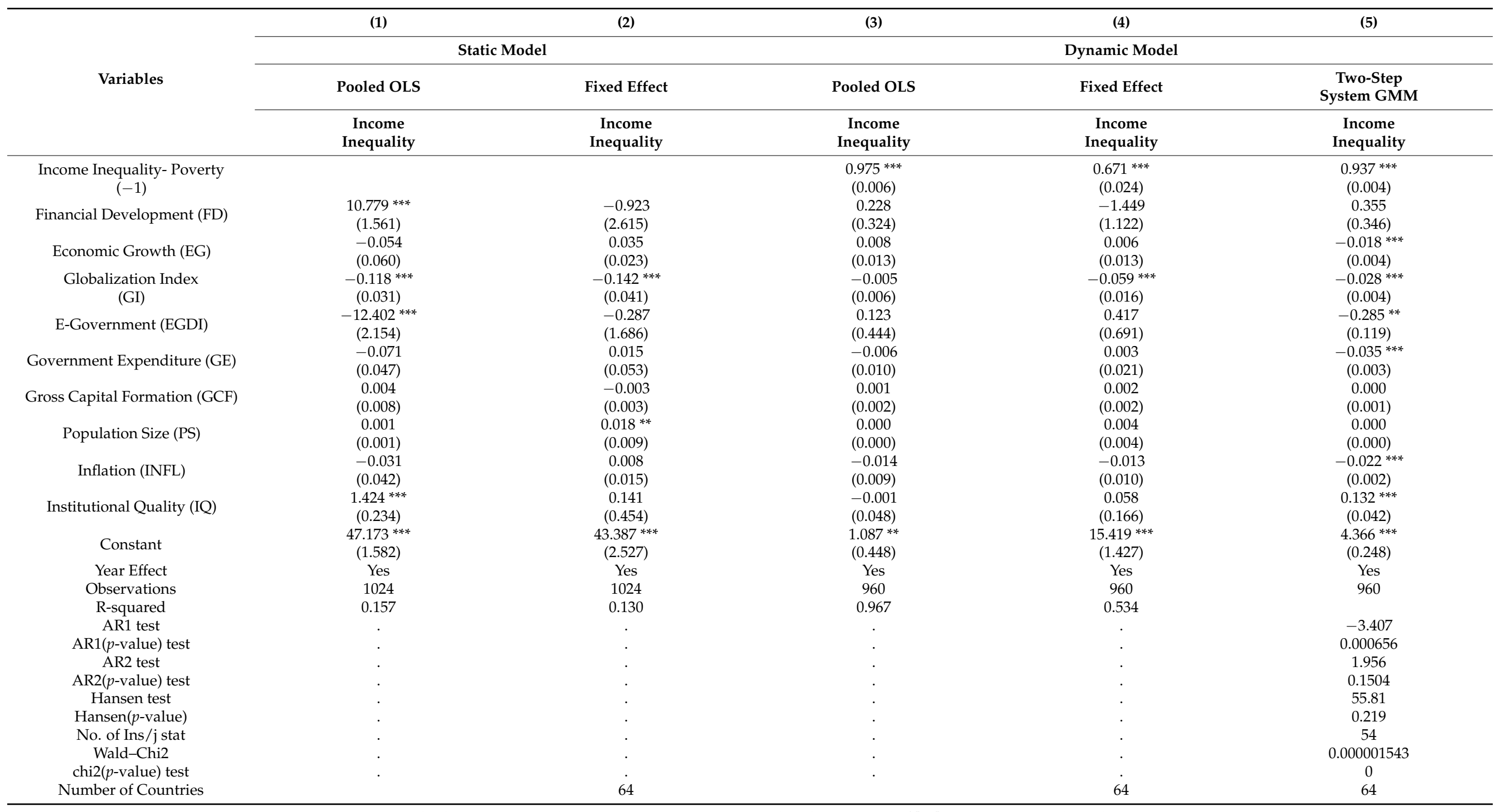


The fifth column in Table 6 reports two-step GMM estimations that indicate more accurate results and robust direct model results. EGDI, EG, GI, GE, and INFL are negative and significant concerning moderating factor IQ with a $1 \%$ significance level. It means that these factors contribute to eradicating poverty. FD and a positive relationship with income inequality employing IQ as a moderating factor means that FD causes an increase in poverty and income inequality level, while GCF and PS have no impact. The moderating variable institutional quality shows a positive relationship with income inequality and poverty, which indicates that quality of institutions in Belt and Road countries are not good enough, as most countries are at the development stage and therefore need to improve institutional quality, which is the major cause of poverty in this modern area. Overall, model results show that the AR(1) $p$-value is 0.000656 , which is less than $5 \%$, indicating the autocorrelation and serial correlation in first-order difference, and the AR2 $p$-value is 0.1504 , greater than $5 \%$, which means that the null hypothesis of second-order difference is not accepted. Furthermore, the Hansen test indicates that overidentifying restrictions are valid where Hansen $p$-value is 0.219 , which is between 0.10 and 0.25 as per the [74] standards that support instrument reliability where the number of instruments, 54, is less than the number of groups, 64, and it fails to reject the null hypothesis. In this model, the Wald Chi-square test indicates that all variables are contributing to the model. The detailed results are reported below.

\subsection{Robustness Check of Driscoll-Kraay Standard Errors Regression}

The results of the direct and indirect model robust check are demonstrated in Table 7 with the DK standard error regression pooled OLS and fixed-effect method. The direct model results of Table 5 for pooled OLS and panel fixed effects are confirmed in the robust DK regression Table 7, Column 1 for OLS and 2 for fixed effects. In addition, the indirect model results of pooled OLS and fixed effects in Table 6 are confirmed in the DK regression Table 7, Columns 3 and 4. The research of [76,77] claimed that DK regression standard errors approach corrects the problems of heteroscedasticity and autocorrelation. Therefore, overall results confirm and endorse the decision toward a two-step system GMM, which is best in examining the endogeneity biases, omitted variables, overidentifying restriction, measurement errors, and controlling the autocorrelation in the panel dataset. Also, GMM is efficient because it is robust to heteroscedasticity and autocorrelation, as the econometric trick of the two-step system GMM includes the best case of OLS, fixed effect, and 2SLS [22,72,74,75]. Detailed results are demonstrated below.

\subsection{Interactions Terms and Factors Affecting Income Inequality}

Table 8 reports the dynamic model two-step system GMM results of interactions' impact on income inequality and relationships with independent factors. Overall, the model's results show that AR(1) $p$-value is less than 5\%, which indicates that autocorrelation and serial correlation in first-order difference and $\operatorname{AR}(2) p$-value are greater than $5 \%$ which means that the null hypothesis of second-order difference is not accepted as per the established standards of [74] as well-reported and recommended by [22,75]. Moreover, the Hansen test indicates that overidentifying restrictions are valid where the Hansen $p$-value supports instrument reliability and fails to reject the null hypothesis. Therefore, system GMM is a valid and excellent technique to apply, as our sample number of cross-sections group " $\mathrm{N}$ ", 64 countries, is greater than the period " $\mathrm{T}$ ", which is 16 years in this study, and instruments are less than the number of groups as per the system GMM-required standards. The summary of results shows that financial development, gross capital formation, and moderating institutional quality positively impact all models. Simultaneously, economic growth, e-government development, globalization, government expenditure, and inflation show a statistically negative effect. This means that these factors contribute to eradicating poverty and income inequality levels. Apart from that, population size shows a statistically positive but sometimes no impact effect. It means that to a degree the population causes an increase in poverty and income inequality, as Belt and Road countries are highly populated. 
Column (1) shows the financial development and institutional quality (governance) interaction term model, which shows the positive and statistically significant impact of financial development and institutional quality. In Column (5) of government expenditure's interaction with moderating variable institutional quality, this also positively impacts income inequality, which indicates that government-level expenditures are not enough to eradicate poverty and income inequality. However, the interaction of economic growth in Column (2) and globalization in Column (3) and in Column (4) the interaction of e-government with institutional quality proves statistically negative on income inequality, which means these factors eradicate poverty in Belt and Road countries. Overall, the summary of interaction models shows that income inequality is significant in all models at the $1 \%$ significance level. Detailed results are shown below.

Table 7. Robustness Check: Driscoll-Kraay Standard Errors Regression (Source: Authors Own Estimations).

\begin{tabular}{|c|c|c|c|c|}
\hline \multirow{2}{*}{ Variables } & (1) & (2) & (3) & (4) \\
\hline & \multicolumn{2}{|c|}{ Robust Direct Model } & \multicolumn{2}{|c|}{ Robust Indirect Model } \\
\hline $\begin{array}{l}\text { Income Inequal- } \\
\text { ity/Poverty }\end{array}$ & \multicolumn{2}{|c|}{$\begin{array}{c}\text { Pooled OLS } \\
\text { (Driscoll and Kraay S.E) }\end{array}$} & \multicolumn{2}{|c|}{$\begin{array}{l}\text { Fixed-effects regression } \\
\text { (Driscoll and Kraay S.E) }\end{array}$} \\
\hline $\begin{array}{l}\text { Financial } \\
\text { Development } \\
\text { (FD) }\end{array}$ & $\begin{array}{c}12.298^{* * * *} \\
(1.187)\end{array}$ & $\begin{array}{c}10.779 * * * * \\
(1.414)\end{array}$ & $\begin{array}{l}-0.889 \\
(1.283)\end{array}$ & $\begin{array}{l}-0.923 \\
(1.321)\end{array}$ \\
\hline $\begin{array}{l}\text { Economic } \\
\text { Growth (EG) }\end{array}$ & $\begin{array}{l}-0.008 \\
(0.059)\end{array}$ & $\begin{array}{l}-0.054 \\
(0.051)\end{array}$ & $\begin{array}{c}0.036 \\
(0.022)\end{array}$ & $\begin{array}{c}0.035 \\
(0.021)\end{array}$ \\
\hline $\begin{array}{l}\text { Globalization } \\
\text { Index } \\
\text { (GI) }\end{array}$ & $\begin{array}{c}-0.098^{* * *} \\
(0.026)\end{array}$ & $\begin{array}{l}-0.118^{* * *} \\
(0.022)\end{array}$ & $\begin{array}{c}-0.138^{* * *} \\
(0.014)\end{array}$ & $\begin{array}{l}-0.142 * * * \\
(0.018)\end{array}$ \\
\hline $\begin{array}{l}\text { E-Government } \\
\text { (EGDI) }\end{array}$ & $\begin{array}{c}-11.107^{* * *} \\
(0.026)\end{array}$ & $\begin{array}{l}-12.402 * * * \\
(2.718)\end{array}$ & $\begin{array}{l}-0.322 \\
(1.057)\end{array}$ & $\begin{array}{l}-0.287 \\
(1.086)\end{array}$ \\
\hline $\begin{array}{c}\text { Government } \\
\text { Expenditure } \\
\text { (GE) }\end{array}$ & $\begin{array}{l}-0.024 \\
(0.026)\end{array}$ & $\begin{array}{c}-0.071^{* *} \\
(0.032)\end{array}$ & $\begin{array}{c}0.015 \\
(0.023)\end{array}$ & $\begin{array}{c}0.015 \\
(0.024)\end{array}$ \\
\hline $\begin{array}{c}\text { Gross Capital } \\
\text { Formation (GCF) }\end{array}$ & $\begin{array}{c}0.004 \\
(0.026)\end{array}$ & $\begin{array}{c}0.004 \\
(0.032)\end{array}$ & $\begin{array}{l}-0.003 \\
(0.004)\end{array}$ & $\begin{array}{l}-0.003 \\
(0.004)\end{array}$ \\
\hline $\begin{array}{l}\text { Population Size } \\
\text { (PS) }\end{array}$ & $\begin{array}{l}-0.000 \\
(0.026)\end{array}$ & $\begin{array}{c}0.001 \\
(0.000)\end{array}$ & $\begin{array}{c}0.018^{* * *} \\
(0.002)\end{array}$ & $\begin{array}{c}0.018^{* * * *} \\
(0.002)\end{array}$ \\
\hline Inflation (INFL) & $\begin{array}{c}-0.079^{* * *} \\
(0.026)\end{array}$ & $\begin{array}{l}-0.031 \\
(0.000)\end{array}$ & $\begin{array}{c}0.007 \\
(0.010)\end{array}$ & $\begin{array}{c}0.008 \\
(0.009)\end{array}$ \\
\hline $\begin{array}{l}\text { Institutional } \\
\text { Quality (IQ) }\end{array}$ & & $\begin{array}{c}1.424^{* * *} \\
(0.100)\end{array}$ & & $\begin{array}{c}0.141 \\
(0.158)\end{array}$ \\
\hline Constant & $\begin{array}{l}44.166^{* * *} \\
(0.026)\end{array}$ & $\begin{array}{l}47.173^{* * *} \\
(0.641)\end{array}$ & $\begin{array}{c}43.149 * * * \\
(1.159)\end{array}$ & $\begin{array}{l}43.387^{* * *} \\
(1.308)\end{array}$ \\
\hline R-squared & 0.1268 & 0.1575 & 0.1293 & 0.1297 \\
\hline Root MSE & 6.1849 & 6.0784 & - & - \\
\hline Prob $>$ F & 0.0000 & 0.0000 & 0.0000 & 0.0000 \\
\hline maximum lag & 2 & 2 & 2 & 2 \\
\hline $\mathrm{F}(8,15)$ & 1081.23 & 2377.37 & 659.36 & 938.51 \\
\hline $\begin{array}{l}\text { Number of } \\
\text { groups }\end{array}$ & 64 & 64 & 64 & 64 \\
\hline Number of Obs. & 1024 & 1024 & 1024 & 1024 \\
\hline
\end{tabular}

Note: Values in the parenthesis are standard errors. ${ }^{* * *} p<0.01,{ }^{* *} p<0.05$, xtset command in Stata 15 was adopted. 
Table 8. Results of Moderating Interactions -Two-step System GMM.

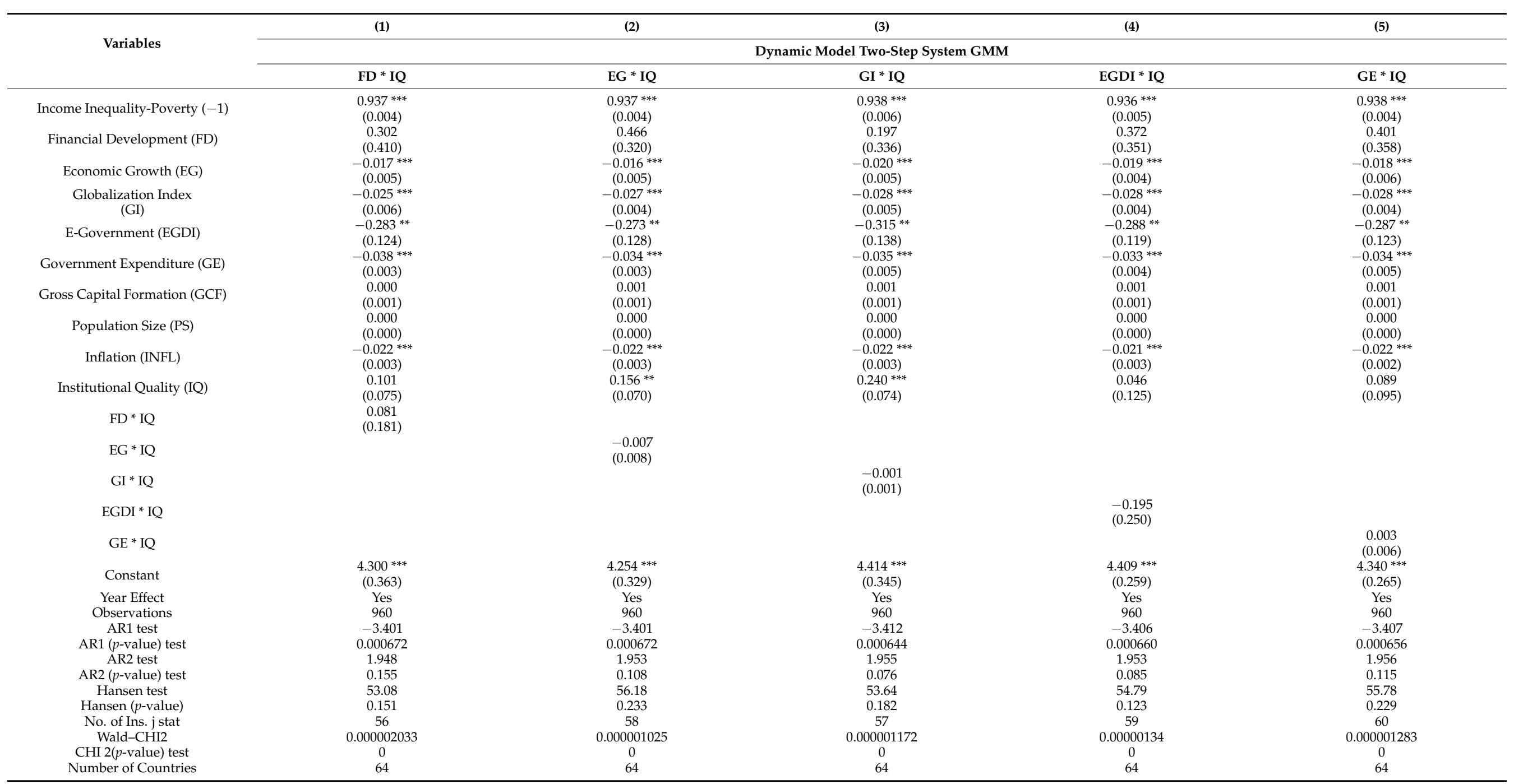

Standard errors in parentheses, ${ }^{* * *} p<0.01,{ }^{* *} p<0.05, * p<0.1$, xtabond 2 command of [74] in Stata 15 was adopted. 


\subsection{Discussion of Results}

We find economic growth to be negatively correlated with income inequality. That direct economic growth and interaction with institutional quality shows a negative impact on income inequality is supported by other studies [42,43]. The globalization index and globalization's interaction with institutional quality is negatively significant in this study with a $1 \%$ significance level, showing a statistically negative influence on income inequality. This finding is consistent with those of other studies [29,46-48]. The e-government direct model and interaction with the moderating variable institutional quality have a negative impact on income inequality at significance level means that e-government development and its factors, such as human capital, technological infrastructure and online services, contribute to eradicating poverty as suggested by [6]. Our study finds that government expenditures have, on average, a less negative impact on income inequality, which is also similar to the findings $[1,12,13]$. The finding confirms that economic growth, globalization, government expenditures, and e-government development are the sources to eradicate poverty and income inequality levels. Inflation also has a negative impact on income inequality, as supported by [12].

Our study finds that the population size is significant at a $1 \%$ significance level, which means that population growth increases the income inequality, as supported by [61], and poverty, as observed by [80,81]. They stated that lower-status groups are more vulnerable to poverty, as they have many family members or dependents. Financial development has a positive impact on income inequality. This shows that income inequality increases by increasing financial development, which is supported by $[38,39]$. Gross capital formation and E-government development index significantly impact income inequality at a $1 \%$ significance level. On the other hand, the interaction of financial development and institutional quality has a positive and statistically significant impact on income inequality. Government expenditure's interaction with institutional quality also positively influences income inequality.

\section{Conclusions}

This study aims to determine the impact of factors affecting income inequality and poverty in One Belt One Road countries with a sample based on the 64 Belt and Road Initiative countries for 2003 to 2018. The dependent variables income inequality and poverty used GINI, while independent variables include GI, EGDI, FD, EG, and GE. Moderating variable institutional quality (governance composite index) was measured based on the PCA of governance's six indicators: rule of law, control of corruption, voice and accountability, government effectiveness, regulatory quality, political stability, and the absence of violence and government effectiveness. Control factors included GCF, PS, and INFL. In this study, we employed cointegration, two-step system GMM and a robust check of results with DK regression. Sys-GMM is best to examine endogeneity biases, omitted variables, overidentifying restrictions, measurement errors, and autocorrelation in a short time panel dataset like 16 years. Overall, the model's results show how overidentifying restrictions are valid and support instrument reliability and fail to reject the null hypothesis. Our findings show that EG, globalization, e-government, and INFL with a $1 \%$ significance level, and GE also have a significantly negative impact on income inequality. On the other hand, financial, GE, GCF, and PS impact positively with a 1\% significance level on income inequality, which causes an increase in poverty. FD and GE's interaction with the moderating variable institutional quality also positively impact income inequality. In comparison, e-government, economic growth, and globalization's interaction with institutional quality shows a statistically negative influence on income inequality and reduces poverty and income inequality in Belt and Road countries.

Our findings endorse and conclude that globalization and e-government development improve economic growth and eradicate poverty and income inequality by boosting digitalization, investments, job creation, and wage increases for the semi-skilled and unskilled labor-intensive workforce in Belt and Road countries. It is noteworthy to move 
towards an approach in an information society which is concerned with leaving no one behind, building resilience, and with sustainable development being entrenched in the development of e-government. Pursuing policies and measures to build resilience is the key responsibility for governments as is supporting those who are distressed by impediments to attaining SDGs. As a new vulnerability dimension, ICTs should maintain or be required to boost resilience in those areas where governments cannot reach or are not highly equipped to venture.

Moreover, institutional quality is important because it provides an incentive structure to an economy and shapes global financial and economic changes towards growth. Development stagnation or decline therefore indicate that in Belt and Road countries institutional quality needs to be emphasized more. It is suggested that poor institutional quality has a detrimental effect on income distribution, which needs to be addressed by poor countries, especially Belt and Road Initiatives countries that are poor or have weak institution systems. Chinese practices will support an excellent deal for socioeconomic growth and poverty alleviation; for example, in about 30 years, China has been able to boost about 700 million individuals living in extreme poverty. The wide variety of ventures in the fields of industry, services, technology, and agriculture under the BRI open a corridor of choices for the allied countries. It is noteworthy here to highlight that there is consent amongst all the stakeholders of the BRI on the fabrication. Emerging markets can upgrade trade and market inauguration, engage in value addition, entrepreneurship, and competitiveness regarding the main traded commodities as well as joining in encouraging business-to-business connections with China and other significant trading allies. Trade tact and productive discussions with member nations are some of the other policy advances that will improve the trade and market entrée. The development of the Gwadar terminal and infrastructure amenities, such as road links, would improve the national economy, and consequently the living standards of people would improve in the allied countries. The current study is limited to 64 countries of the Belt and Road Initiative, while more than 70 countries became part of this initiative. Countries like Iran, Afghanistan, Cameroon, Antigua, and Barbuda, etc., are not included in the sample because of incomplete data. This research used an institutional quality composite of World Bank Governance indicators which future studies can adopt or compare with the International Country Guide Risk database alternate indicators of institutional quality. Future studies should consider the factors affecting sustainable development and regional global integration in Belt and Road countries.

Author Contributions: Conceptualization, A.U. and S.K.; methodology, A.U. and S.U; software, A.U.; validation, S.U., Z.K. and C.P.; formal analysis, A.U.; investigation, A.U, and S.K.; resources, C.P and Z.K.; data curation, A.U.; writing — original draft preparation, A.U and S.K.; writing-review and editing, S.U. and Z.K.; visualization, S.U and C.P.; supervision, C.P.; project administration, C.P.; funding acquisition, C.P and Z.K. All authors have read and agreed to the published version of the manuscript. All Authors contributed, read, and agreed to the published version of the manuscript.

Funding: This Work Supported by the Huazhong University of Science and Technology, Wuhan, China, School of Management, Institute of Poverty Reduction and Development, supported by Professor Chen Pinglu.

Institutional Review Board Statement: Not applicable.

Informed Consent Statement: Not applicable.

Data Availability Statement: Data available on request of researcher.

Acknowledgments: We acknowledge the mentorship, guidance and supervision of Chen Pinglu during the whole process. We are very grateful to the Guest-editor's, and anonymous reviewers for their helpful comments and suggestions which improved the draft.

Conflicts of Interest: The authors declare no conflict of interest. 


\section{Appendix A}

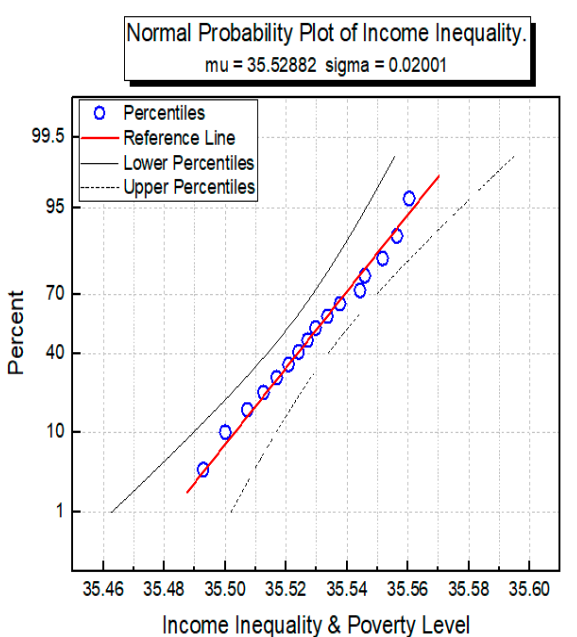

(a)

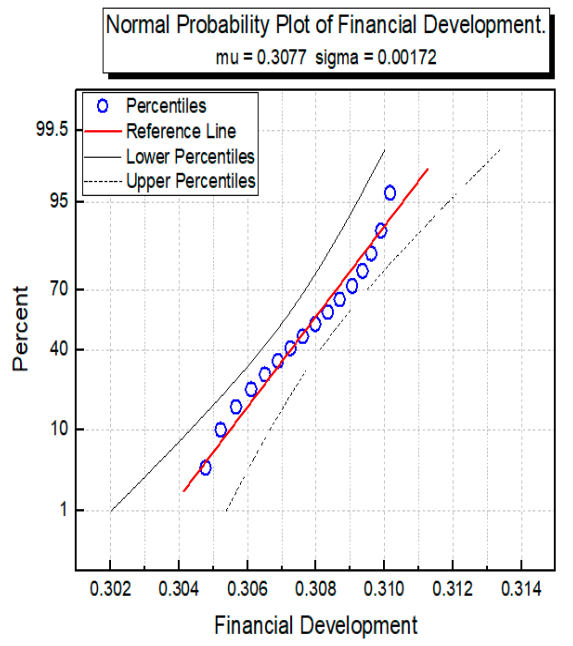

(c)

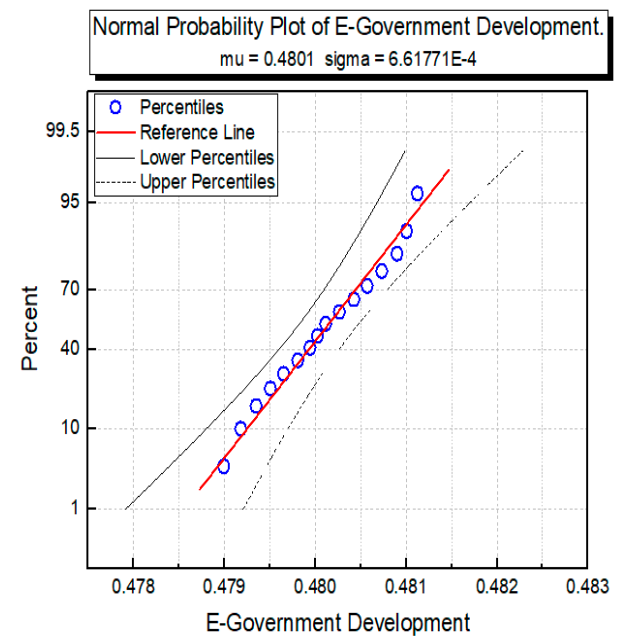

(e)

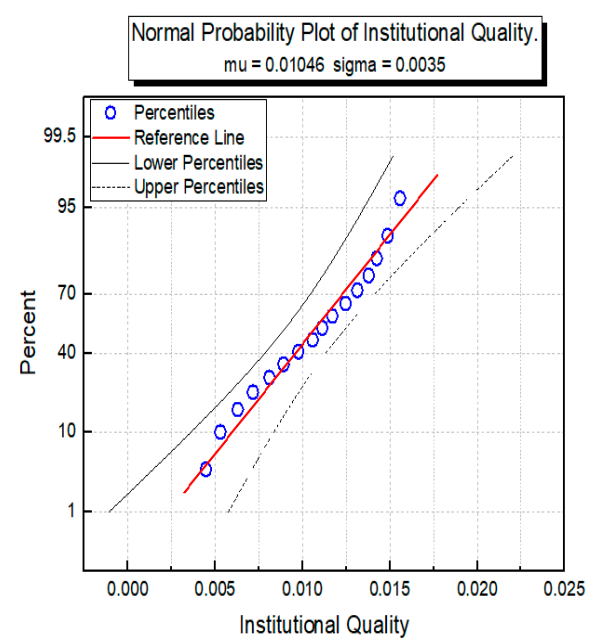

(b)

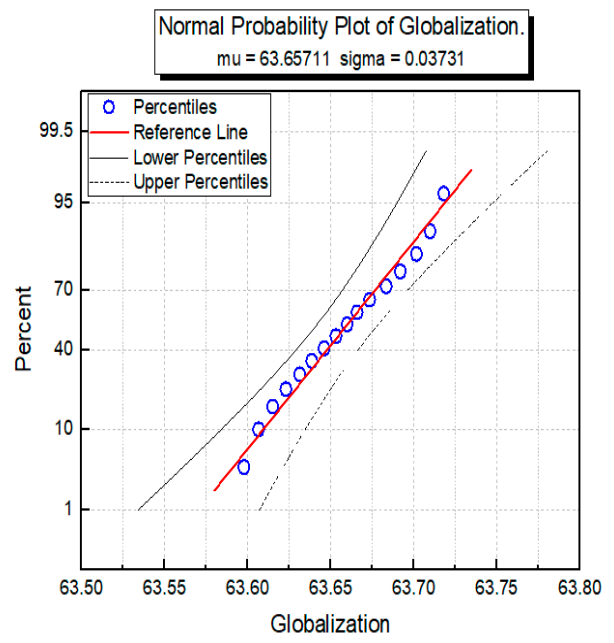

(d)

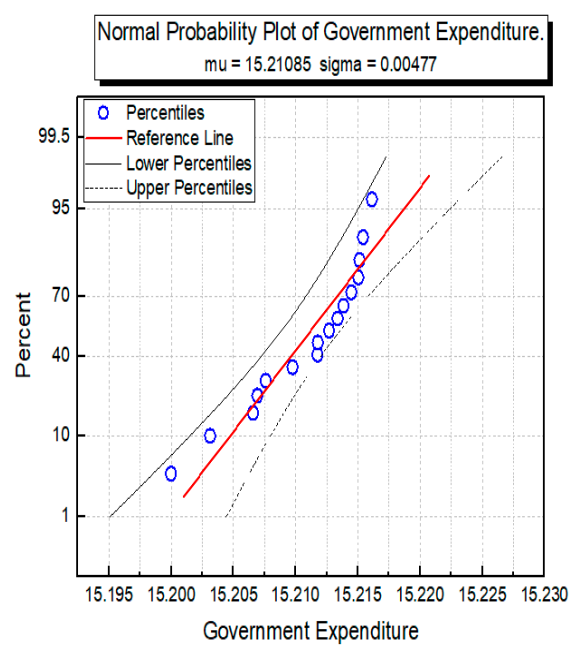

(f)

Figure A1. Cont. 


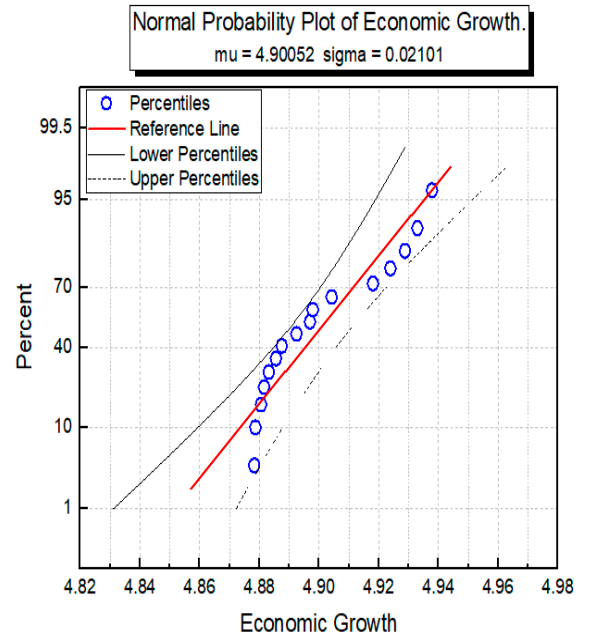

(g)

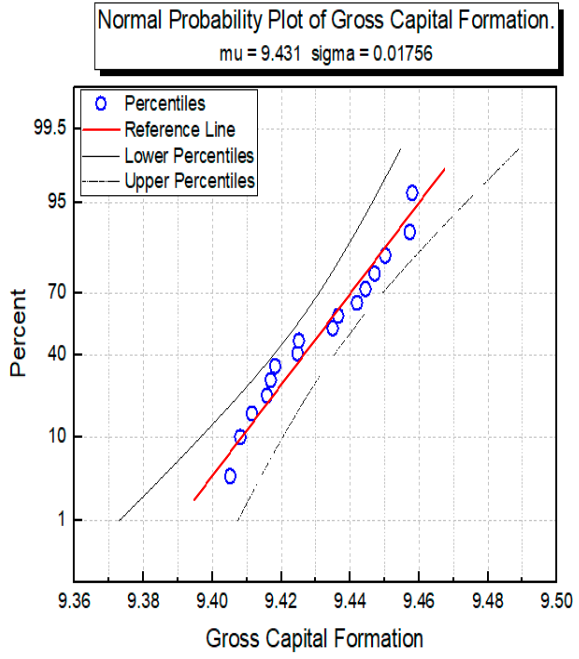

(i)

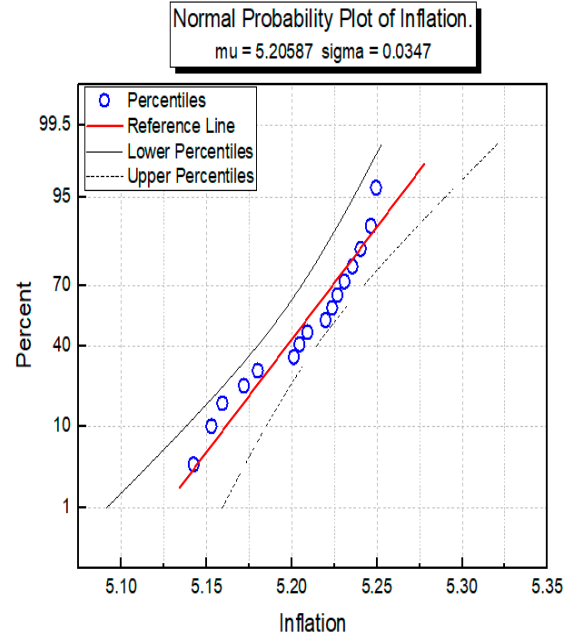

(h)

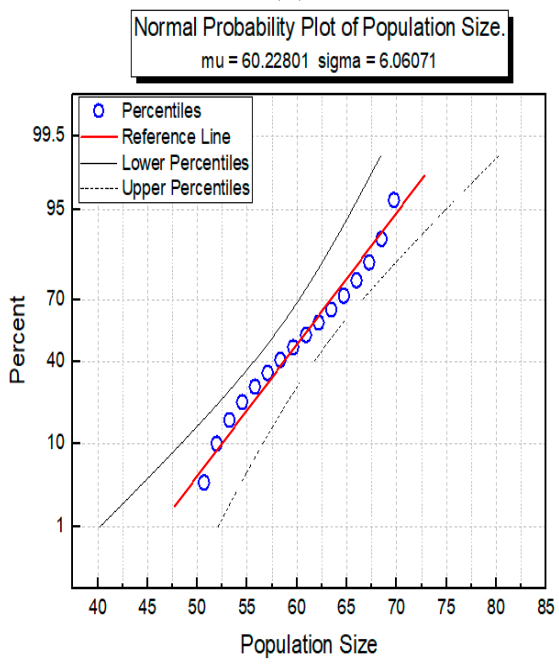

(j)

Figure A1. Normal Distribution of Variables.

\section{References}

1. Anderson, E.; d'Orey, M.A.J.; Duvendack, M.; Esposito, L. Does government spending affect income poverty? A meta-regression analysis. World Dev. 2018, 103, 60-71. [CrossRef]

2. World-Bank. "Poverty, Ending Prosperity, Sharing" Global Monitoring Report 2014/15; International Bank for Reconstruction Development/The World Bank: Washington, DC, USA, 2015; Volume 240.

3. Kavya, T.; Shijin, S. Economic development, financial development, and income inequality nexus. Borsa Istanb. Rev. 2020. [CrossRef]

4. Wang, J.J.; Selina, Y. Case studies on transport infrastructure projects in belt and road initiative: An actor network theory perspective. J. Transp. Geogr. 2018, 71, 213-223. [CrossRef]

5. Tambo, E.; Khayeka-Wandabwa, C.; Muchiri, G.W.; Liu, Y.-N.; Tang, S.; Zhou, X.-N. China's Belt and Road Initiative: Incorporating public health measures toward global economic growth and shared prosperity. Global Health J. 2019, 3, 46-49. [CrossRef]

6. Ullah, A.; Pinglu, C.; Ullah, S.; Abbas, H.S.M.; Khan, S. The Role of E-Governance in Combating COVID-19 and Promoting Sustainable Development: A Comparative Study of China and Pakistan. Chin. Political Sci. Rev. 2020, 1-33. [CrossRef]

7. Zhang, Q.; Chen, R. Financial development and income inequality in China: An application of SVAR approach. Procedia Comput. Sci. 2015, 55, 774-781. [CrossRef]

8. Shahbaz, M.; Loganathan, N.; Tiwari, A.K.; Sherafatian-Jahromi, R. Financial development and income inequality: Is there any financial Kuznets curve in Iran? Soc. Indic. Res. 2015, 124, 357-382. [CrossRef]

9. Nikoloski, Z. Financial sector development and inequality: Is there a financial Kuznets curve? J. Int. Dev. 2013, 25, 897-911. [CrossRef]

10. Younsi, M.; Bechtini, M. Economic Growth, Financial Development, and Income Inequality in BRICS Countries: Does Kuznets' Inverted U-Shaped Curve Exist? J. Knowl. Econ. 2020, 11, 721-742. [CrossRef] 
11. Rashid, A.; Intartaglia, M. Financial development-does it lessen poverty? J. Econ. Stud. 2017. [CrossRef]

12. Destek, M.A.; Sinha, A.; Sarkodie, S.A. The relationship between financial development and income inequality in Turkey. J. Econ. Struct. 2020, 9, 11. [CrossRef]

13. Alamanda, A. The Effect of Government Expenditure on Income Inequality and Poverty in Indonesia. INFO ARTHA 2020, 4, 1-11. [CrossRef]

14. Haseeb, M.; Suryanto, T.; Hartani, N.H.; Jermsittiparsert, K. Nexus Between Globalization, Income Inequality and Human Development in Indonesian Economy: Evidence from Application of Partial and Multiple Wavelet Coherence. Soc. Indic. Res. 2020, 147, 723-745. [CrossRef]

15. Osinubi, T.T.; Olomola, P.A. Globalisation, income inequality and poverty relationships: Evidence from Mexico, Indonesia, Nigeria and Turkey. J. Econ. Adm. Sci. 2020. [CrossRef]

16. Seven, U.; Coskun, Y. Does financial development reduce income inequality and poverty? Evidence from emerging countries. Emerg. Mark. Rev. 2016, 26, 34-63. [CrossRef]

17. Im, H.; McLaren, J. Does foreign direct investment raise income inequality in developing countries? A new instrumental variables approach. Sch. Econ. Financ. Yeungnam Univ. 2015, 1, 1-58.

18. Dong, F. The impact of economic openness on standard of living and income inequality in eight countries. Emerg. Mark. Rev. 2014, 21, 234-264. [CrossRef]

19. Chaudhry, I.S.; Imran, F. Does trade liberalization reduce poverty and inequality? Empirical evidence from Pakistan. Pakistan J. Commer. Soc. Sci. 2013, 7, 569-587.

20. Lee, C.-C.; Lee, C.-C.; Lien, D. Income inequality, globalization, and country risk: A cross-country analysis. Technol. Econ. Dev. Econ. 2020, 26, 379-404. [CrossRef]

21. Goh, L.T.; Law, S.H. The Effect of Trade Openness on Income Inequality with the Role of Institutional Quality. Indones. J. Econ. Soc. Humanit. 2019, 1, 65-76. [CrossRef]

22. Abbas, H.S.M.; Gillani, S.; Ullah, S.; Raza, M.A.A.; Ullah, A. Nexus Between Governance and Socioeconomic Factors on Public Service Fragility in Asian Economies. Soc. Sci. Q. 2020. [CrossRef]

23. Rewilak, J. The role of financial development in poverty reduction. Rev. Dev. Financ. 2017, 7, 169-176. [CrossRef]

24. Donou-Adonsou, F.; Sylwester, K. Financial development and poverty reduction in developing countries: New evidence from banks and microfinance institutions. Rev. Dev. Financ. 2016, 6, 82-90. [CrossRef]

25. Chen, J.; Wang, Y.; Wen, J.; Fang, F.; Song, M. The influences of aging population and economic growth on Chinese rural poverty. J. Rural Stud. 2016, 47, 665-676. [CrossRef]

26. Moore, J.D.; Donaldson, J.A. Human-scale economics: Economic growth and poverty reduction in Northeastern Thailand. World Dev. 2016, 85, 1-15. [CrossRef]

27. Amini, C.; Dal Bianco, S. Poverty elasticity to growth and inequality: New evidence from macro data. J. Dev. Areas 2016, 50. [CrossRef]

28. Kazungu, K.G.; Cheyo, M.B. Government expenditure on growth strategies and poverty reduction in Tanzania. What have we learned? Afr. J. Econ. Rev. 2014, 2, 38-47.

29. Liyanaarachchi, T.S.; Naranpanawa, A.; Bandara, J.S. Impact of trade liberalisation on labour market and poverty in Sri Lanka. An integrated macro-micro modelling approach. Econ. Model. 2016, 59, 102-115. [CrossRef]

30. Le Goff, M.; Singh, R.J. Does Trade Reduce Poverty? A View from Africa. J. Afr. Trade 2013, 1, 5-14. [CrossRef]

31. Inoue, T. Financial development, remittances, and poverty reduction: Empirical evidence from a macroeconomic viewpoint. J. Econ. Bus. 2018, 96, 59-68. [CrossRef]

32. Marinho, E.; Campelo, G.; França, J.; Araujo, J. Impact of infrastructure expenses in strategic sectors for Brazilian poverty. EconomiA 2017, 18, 244-259. [CrossRef]

33. Parikh, P.; Fu, K.; Parikh, H.; McRobie, A.; George, G. Infrastructure provision, gender, and poverty in Indian slums. World Dev. 2015, 66, 468-486. [CrossRef]

34. Magombeyi, M.T.; Odhiambo, N.M. Dynamic impact of FDI inflows on poverty reduction: Empirical evidence from South Africa. Sustain. Cities Soc. 2018, 39, 519-526. [CrossRef]

35. Soumaré, I. Does FDI improve economic development in North African countries? Appl. Econ. 2015, 47, 5510-5533. [CrossRef]

36. Fowowe, B.; Shuaibu, M.I. Is foreign direct investment good for the poor? New evidence from African countries. Econ. Chang. Restruct. 2014, 47, 321-339. [CrossRef]

37. Motaghi, S.; Ranjbar Fallah, M.R.; Ebrahimi, S. An Analytical Examination of the Effects of Financial Development on Poverty. Int. J. Financ. Manag. Account. 2020, 5, 107-113.

38. Jung, S.M.; Cha, H.E. Financial development and income inequality: Evidence from China. J. Asia Pac. Econ. 2020, 1-23. [CrossRef]

39. Ngangu, N. Financial Sector Development and Open Economy for Income Inequality Reduction: A Panel Fixed Model Analysis. Int. J. Econ. Financ. 2020, 12, 1-33. [CrossRef]

40. Koomson, I.; Villano, R.A.; Hadley, D. Effect of financial inclusion on poverty and vulnerability to poverty: Evidence using a multidimensional measure of financial inclusion. Soc. Indic. Res. 2020, 1-27. [CrossRef]

41. Islam, R.; Ghani, A.B.A.; Abidin, I.Z.; Rayaiappan, J.M. Impact on poverty and income inequality in Malaysia's economic growth. Probl. Perspect. Manag. 2017. [CrossRef] 
42. Bouincha, M.; Karim, M. Income inequality and economic growth: An analysis using a panel data. Int. J. Econ. Financ. 2018, 10, 242-253. [CrossRef]

43. Vo, D.H.; Nguyen, T.C.; Tran, N.P. What Factors Affect Income Inequality and Economic Growth in Middle-Income Countries? J. Risk Financ. Manag. 2019, 12, 40. [CrossRef]

44. Philips, A.Q.; Souza, F.D.; Whitten, G.D. Globalization and comparative compositional inequality. Political Sci. Res. Methods 2019, 8, 509-525. [CrossRef]

45. Uddin, M.N. Bangladesh: Income Inequality and Globalization. Asian Bus. Rev. 2020, 10, 43-52. [CrossRef]

46. Teixeira, A.A.; Loureiro, A.S. FDI, income inequality and poverty: A time series analysis of Portugal, 1973-2016. Port. Econ. J. 2019, 18, 203-249. [CrossRef]

47. Mahadevan, R.; Nugroho, A.; Amir, H. Do inward looking trade policies affect poverty and income inequality? Evidence from Indonesia's recent wave of rising protectionism. Econ. Model. 2017, 62, 23-34. [CrossRef]

48. Zhang, R.; Naceur, S.B. Financial development, inequality, and poverty: Some international evidence. Int. Rev. Econ. Financ. 2019, 61, 1-16. [CrossRef]

49. Bergh, A.; Mirkina, I.; Nilsson, T. Can social spending cushion the inequality effect of globalization? Econ. Politics 2020, 32, 104-142. [CrossRef]

50. Hepenstrick, C.; Tarasov, A. Trade Openness and Cross-country Income Differences. Rev. Int. Econ. 2015, 23, 271-302. [CrossRef]

51. Ezcurra, R.; Rodríguez-Pose, A. Does economic globalization affect regional inequality? A cross-country analysis. World Dev. 2013, 52, 92-103. [CrossRef]

52. Beck, T.; Demirgüç-Kunt, A.; Levine, R. Finance, inequality and the poor. J. Econ. Growth 2007, 12, 27-49. [CrossRef]

53. Demir, F.; Ju, J.; Zhou, Y. Income inequality and structures of international trade. Asia-Pac. J. Account. Econ. 2012, 19, 167-180. [CrossRef]

54. Máchová, R.; Volejníková, J.; Lněnička, M. Impact of e-government development on the level of corruption: Measuring the effects of related indices in time and dimensions. Rev. Econ. Perspect. 2018, 18, 99-121. [CrossRef]

55. Rubtsova, A.V.; Almazova, A.; Eremin, U. Innovative productive method of teaching foreign languages to international students. In Proceedings of the 18th PCSF 2018-Professional Culture of the Specialist of the Future, St Petersburg, Russia, 28-30 November 2018. [CrossRef]

56. Sasana, H.; Kusuma, P. Government expenditure and poverty in Indonesia. KnE Soc. Sci. 2018, 142-153. [CrossRef]

57. Iqbal, A.; Mehar, A. Governance Issues in Pakistan and their Impact on Income Inequality. IBT J. Bus. Stud. 2015, 11, 213-228.

58. Huang, C.-J.; Ho, Y.-H. The Impact of Governance on Income Inequality in Ten Asian Countries. J. Rev. Glob. Econ. 2018, 7, 217-224. [CrossRef]

59. Akobeng, E. Gross Capital Formation, Institutions and Poverty in Sub-Saharan Africa. J. Econ. Policy Reform 2017, 20, 136-164. [CrossRef]

60. Meyer, D.F.; Sanusi, K.A. A Causality Analysis of the Relationships Between Gross Fixed Capital Formation, Economic Growth and Employment in South Africa. Studia Univ. Babes-Bolyai Oeconomica 2019, 64, 33-44. [CrossRef]

61. Bekele, D.; Merid, A.S. Determinants of poverty in rural Ethiopia: Evidence from Tenta woreda, Amhara Region. J. Sustain. Rural Dev. 2020, 3, 3-14. [CrossRef]

62. Cardoso, E.; Barros, R.; Urani, A. Inflation and Unemployment as Determinants of Inequality in Brazil: The 1980; Instituto de Pesquisa Econômica Aplicada-IPEA, University of Chicago Press: Chicago, IL, USA, 2015.

63. Khattak, D.; Muhammad, A.; Iqbal, K. Determining the relationship between income inequality, economic growth \& inflation. J. Soc. Econ. 2014, 1, 104-114.

64. Bertola, G. Inequality, integration, and policy: Issues and evidence from EMU. J. Econ. Inequal. 2010, 8, 345-365. [CrossRef]

65. Siami-Namini, S.; Hudson, D. Inflation and income inequality in developed and developing countries. J. Econ. Stud. 2019. [CrossRef]

66. Thalassinos, E.; Ugurlu, E.; Muratoglu, Y. Income Inequality and Inflation in the EU. Eur. Res. Stud. J. 2012, 15, 127-140. [CrossRef]

67. Meo, M.S.; Khan, V.J.; Ibrahim, T.O.; Khan, S.; Ali, S.; Noor, K. Asymmetric impact of inflation and unemployment on poverty in Pakistan: New evidence from asymmetric ARDL cointegration. Asia Pac. J. Soc. Work Dev. 2018, 28, 295-310. [CrossRef]

68. Sugema, I.; Irawan, T.; Adipurwanto, D.; Holis, A.; Bakhtiar, T. The impact of inflation on rural poverty in Indonesia: An econometrics approach. Int. Res. J. Financ. Econ. 2010, 58, 51-57.

69. Svirydzenka, K. Introducing a new broad-based index of financial developmentIMF Working Paper, WP/16/5Strategy, Policy, and Review Department: Washington, DC, USA, 2016. [CrossRef]

70. Islam, M.A.; Khan, M.A.; Popp, J.; Sroka, W.; Oláh, J. Financial Development and Foreign Direct Investment-The Moderating Role of Quality Institutions. Sustainability 2020, 12, 3556. [CrossRef]

71. Khan, M.A.; Khan, M.A.; Abdulahi, M.E.; Liaqat, I.; Shah, S.S.H. Institutional quality and financial development: The United States perspective. J. Multinatl. Financ. Manag. 2019, 49, 67-80. [CrossRef]

72. Arellano, M.; Bond, S. Some tests of specification for panel data: Monte Carlo evidence and an application to employment equations. Rev. Econ. Stud. 1991, 58, 277-297. [CrossRef]

73. Ozkan, A.; Ozkan, N. Corporate cash holdings: An empirical investigation of UK companies. J. Bank. Financ. 2004, 28, 2103-2134. [CrossRef]

74. Roodman, D. How to do xtabond2: An introduction to difference and system GMM in Stata. Stata J. 2009, 9, 86-136. [CrossRef] 
75. Adeleye, N.; Eboagu, C. Evaluation of ICT development and economic growth in Africa. NETNOMICS Econ. Res. Electron. Netw. 2019, 20, 31-53. [CrossRef]

76. Driscoll, J.C.; Kraay, A.C. Consistent covariance matrix estimation with spatially dependent panel data. Rev. Econ. Stat. 1998, 80, 549-560. [CrossRef]

77. Dar, A.A.; Muhammad, T.; Siddiqi, M.W. Bureaucratic Quality and FDI Inflows Nexus: A South Asian Perspective. Rom. J. Econ. Forecast. 2020, 23, 149.

78. Arminen, H.; Menegaki, A.N. Corruption, climate and the energy-environment-growth nexus. Energy Econ. 2019, 80, 621-634. [CrossRef]

79. Ahmad, M.; Khattak, S.I.; Khan, A.; Rahman, Z.U. Innovation, foreign direct investment (FDI), and the energy-pollution-growth nexus in OECD region: A simultaneous equation modeling approach. Environ. Ecol. Stat. 2020, 27, 203-232. [CrossRef]

80. Dribe, M.; Breschi, M.; Gagnon, A.; Gauvreau, D.; Hanson, H.A.; Maloney, T.N.; Mazzoni, S.; Molitoris, J.; Pozzi, L.; Smith, K.R. Socio-economic status and fertility decline: Insights from historical transitions in Europe and North America. Popul. Stud. 2017, 71, 3-21. [CrossRef]

81. Canning, D.; Raja, S.; Yazbeck, A.S. Africa's Demographic Transition: Dividend or Disaster? The World Bank: Washington, DC, USA, 2015. [CrossRef] 